\title{
Lietuvos viešųjų bibliotekų veikla COVID-19 pandemijos ir migrantų krizės akivaizdoje: siekis užtikrinti žmogaus teises
}

\author{
Rasa Januševičienè \\ Lietuvos nacionalinès Martyno Mažvydo bibliotekos \\ Informacijos ir komunikacijos mokslų departamentas \\ Department of Information and Communication Sciences \\ at the Martynas Mažvydas National Library of Lithuania \\ rasa.januseviciene@lnb.lt
}

\begin{abstract}
Santrauka. Remiantis dalyko literatūros analize ir empirinio tyrimo rezultatais straipsnyje siekiama apibendrinti Lietuvos viešųjų bibliotekų veiklą užtikrinant žmogaus teisių igyvendinimą COVID-19 pandemijos ir migrantų krizès sąlygomis bei pateikti viešosioms bibliotekoms rekomendacijas, kaip prisidèti prie nūdienos krizių sukeltų problemų sprendimų šalyje. Tyrimo rezultatai atskleide, kad Lietuvos viešujų bibliotekų veiklos COVID-19 pandemijos kontekste ir migrantų krizès akivaizdoje labiausiai orientuotos užtikrinti šių sričių žmogaus teises: prieigą prie patikimų žinių ir informacijos; mokymą(si) ir švietimą; bibliotekos vartotojų lygias galimybes; dalyvavimą bendruomenės kultūriniame gyvenime; sveikos gyvensenos puoselëjimą. Prisidedant prie nūdienos krizių sukeltų problemų sprendimų šalyje, viešosioms bibliotekoms rekomenduojama skirti ypatingą dèmesį medijų ir informacinio raštingumo veikloms ir programoms; sparčiau gerinti fizinę ir informacinę viešųjų bibliotekų infrastruktūrą, skirtą negalią turintiems žmonèms; remiantis pasaulio viešųjų bibliotekų patirtimi, plèsti (tiek i̇ gyli, tiek ỉ plotị) viešųjų bibliotekų dalyvavimą migrantų socialinės integracijos programose; rengti bendruomenès ir potencialių vartotojų poreikių tyrimus.
\end{abstract}

Reikšminiai žodžiai: Lietuvos viešosios bibliotekos, COVID-19 pandemija, migrantų krizè, žmogaus teisès, imigrantų integracija.

\section{Activities of Lithuanian Public Libraries in the Face of the COVID-19 Pandemic and Migrant Crisis: the Endeavour to Ensure Human Rights}

\begin{abstract}
By drawing on subject literature analysis and the results from empirical research, the article purports to generalize activities of Lithuania's public libraries in ensuring the reinforcement of human rights during the COVID-19 pandemic and migrant crisis as well as to present recommendations for public libraries how to contribute to solving issues caused by today's crises in Lithuania. The research results showed that activities of Lithuanian public libraries in the context of the COVID-19 pandemic and migrant crisis are mostly oriented at safeguarding the following areas of human rights: provision of access to trustful knowledge and information, training / learning and education, ensuring equal possibilities for all library users, participation in the cultural life of the community, and fostering healthy lifestyle. In their contribution to solving issues caused by today's crises in Lithuania, public libraries are recommended to focus primarily on activities and programmes related to media and information literacy; to more rapidly improve their physical and informational infrastructure intended for people with disabilities; by building on the experience of the world's libraries, to both reinforce and expand their participation in programmes for social integration of migrants; and to do studies on potential demands of users.
\end{abstract}

Keywords: Lithuanian public libraries, COVID-19 pandemic, migrant crisis, human rights, integration of immigrants. 


\section{İvadas}

Lietuvos bibliotekos 2020-2021 m. veikia kelių šalies patiriamų krizių sąlygomis: pandemijos, visuomenejje kylančiu neramumų ir didesnès, nei Lietuvos Respublika kada nors buvo susidūrusi, imigracijos akivaizdoje.

Užklupus COVID-19 pandemijai, 2020 m. daugumos pasaulio šalių bibliotekos, kaip ir kitos viešąsias paslaugas teikiančios įstaigos, fiziniams lankytojams buvo uždarytos. Neturint veiklos pandemijos sąlygomis patirties, Tarptautinè bibliotekų asociacijų ir institucijų federacija (toliau - IFLA), Amerikos bibliotekų asociacija (toliau - ALA), Europos bibliotekų, informacijos ir dokumentacijos asociacijų biuras (toliau - EBLIDA), kitos tarptautinès ir nacionalinès bibliotekų asociacijos, nacionalinès ir didžiosios šalių bibliotekos èmėsi iniciatyvos operatyviai rinkti, kaupti ir skleisti informaciją apie priimtus ivvairiose šalyse sprendimus dèl bibliotekų veiklos, siekdamos užtikrinti maksimalią vartotojų, darbuotojų, informacijos išteklių apsaugą ir galimybes teikti ir gauti bibliotekų ir informacijos paslaugas, esant nepaprastajai padèčiai ${ }^{1}$. Organizuoti tyrimai, skelbtos jų išvados ir bibliotekų veiklos rekomendacijos, IFLA $^{2}$ ir $\mathrm{ALA}^{3}$ savo tinklalapiuose sukūrè pandemijos temai skirtus skyrius. İ naujų, aktualių žinių apie informacijos procesų ir informacijos paslaugų kūrimą, kaupimą ir sklaidą pandemijos laikotarpiu aktyviai ịsitraukè nacionalinès ir didžiosios šalių bibliotekos. Lietuvos nacionalinė Martyno Mažvydo biblioteka, remdamasi operatyviai atliekamų tyrimų išvadomis, vietine ir tarptautine patirtimi, rengè bibliotekų sektoriaus veiklos karantino ir švelninamo karantino sąlygomis rekomendacijas. Tad galima teigti, kad Lietuvos (kaip ir daugelio kitų pasaulio šalių) bibliotekos savo veikla COVID-19 pandemijos akivaizdoje prisideda prie žmogaus teisių igyvendinimo. Aktualiausios bibliotekų veikloje yra šių sričių žmogaus teisès:

- teisè gauti informaciją;

- prieiga prie žinių ir informacijos;

- teisè $\mathfrak{i}$ informaciją iš patikimų šaltinių (t. y. ị oficialiąją, valstybès institucijų ir ịstaigų parengtą informaciją);

- teisè į mokymą(si) ir švietimą;

- lygių galimybių visiems visuomenės ir bibliotekų aptarnaujamos bendruomenès nariams sudarymas, nediskriminavimas;

- teisè dalyvauti bendruomenès kultūriniame gyvenime;

- teisè ị sveikatą.

Kita vertus, viešųjų bibliotekų galia mokyti visuomenę ir siekti bendruomeniškumo, pagarbos, supratimo yra aktuali ne tik krizių (pandemijų), bet ir esamos ar potencialios migrantų krizès fone. JAV, Vakarų ir Šiaurès Europos valstybių viešosios bibliotekos turi didelị įdirbị kuriant paslaugas imigrantams iš Azijos ir Afrikos šalių ${ }^{4}$. Lietuvos viešosios bibliotekos pastaraisiais dešimtmečiais taip pat kaupè patirti daugiakultūrès bibliotekos prielaidoms sukurti ${ }^{5}$, tačiau situacija, su kuria susidūrè Lietuvos Respublika

Žr., pavyzdžiui: EBLIDAঊCOVID-19: A European Library Agenda for the Post-Covid 19 Age Work in Progress. Prieiga per internetą: http://www.eblida.org/publications/eblida-and-covid-19.html. Žiūrèta 2021-08-27.

COVID-19 and the Global Library Field: Statement by the IFLA President and Secretary General, 23 March 2020. Prieiga per internetą: https://www.ifla.org/covid-19-and-libraries. Žiūrèta 2021-08-23.

ALA (American Library Association): COVID-19 Recovery: Making Connections during Crisis and Plothing the Path to Reopening. Prieiga per internetą: https://www.ala.org/tools/covid-19-recovery. Žiūrèta 2021-08-23.

Žr. Library Services for Immigrants: A Report of Current Practices. U.S. Citizenship and Immgration Services: Institute of Museum and Library Services. Prieiga per internetą: https://www.uscis.gov/sites/default/files/document/guides/G-1112.pdf. Žiūrèta 2021-08-23; Libraries as a Gateways to the Integration of Immigrants in the EU / Editors L. Špačkova, J. Štefkova. Multicultural Center Prague, 2006. Prieiga per internetą: https://mkc.cz/doc/Libraries_as_Gateways.pdf. Žiūrèta 2021-08-23.

Žr. Daugiakultūrio dialogo biblioteka: darbo su migrantais gairès / sudarytojos E. Dikavičienė, B. Dženkaitienė, D. Ivanovienė, E. Puskunigytė, A. Vaškevičienė, R. Zenevskienè. Vilnius: Lietuvos nacionalinė Martyno Mažvydo biblioteka, 2018. Prieiga per internetą: http://eia.libis.lt/show.php?item=daugiakulturinio_dia. Žiūrèta 2021-09-30. 
$2021 \mathrm{~m}$. vasarą, yra visiškai nauja; dèl jos paskelbta valstybès lygio ekstremalioji padètis ${ }^{6}$. Per trumpą laikotarpi Lietuva ir kitos su migrantų krize susiduriančios valstybès jau yra gavusios Europos instituciju pastabų dèl žmogaus teisių užtikrinimo. Tačiau krizès sukeltoje naujoje situacijoje pastebima, kad žmogaus teises apibrěžiantys dokumentai turi būti atnaujinti - kai kurių žmogaus teisių formuluotès tiesiog utopinės, nebeatitinkančios realijų. Diskusijos žmogaus teisių tema ima aštrèti. Vienu metu vykstančių kelių krizių išsekintai visuomenei reikia suteikti daugiau žinių, atsakymų ị kylančius klausimus, sudaryti galimybę susitikti su kompetentingais, galinčiais ị juos atsakyti asmenimis. Kita vertus, Lietuvos visuomenè baiminasi, kad migrantai (naudojami kaip hibridinès atakos priemonè) kelia grèsmę valstybès nacionaliniam saugumui, stabilumui, vertybèms. Valstybès ištekliai yra riboti. Migracija turi neigiamą šleifą, yra apipinta mitais, stereotipais, sukurtas neigiamas migranto įvaizdis ${ }^{7}$. Trūksta informacijos ir suvokimo apie realią migracijos situaciją, dalị visuomenès užvaldęs neužtikrintumas, kitoniškumo bai$\mathrm{me}^{8}$. Galiausiai, be nelegalių migrantų, $\mathfrak{i}$ Lietuvą po Afganistane ịvykdytų valstybinių permainų ir tarptautinių karinių pajegų išvedimo atgabenti Lietuvos kariams šioje šalyje talkinę vertėjai su šeimomis. Šių naujųjų Lietuvos gyventojų padètis ir statusas yra kitokie nei nelegalių migrantų, tačiau tai šio straipsnio kontekste reikètų įvertinti kaip faktą, kad šalyje yra naujų gyventojų, kuriems bus kuriamos integracijos programos .

Konstatuotina, kad per pirmą COVID-19 pandemijos karantiną 2020 m. pavasarị Lietuvos viešosios bibliotekos gerokai prisidejo prie kovos su melagingomis naujienomis skelbdamos oficialią informaciją iš patikimų šaltinių. Tęsti ir plètoti šią veiklą migrantų krizės akivaizdoje yra ir būtų svarbi bei reikšminga viešųjų bibliotekų misija. Jos sėkmę didina tai, kad Lietuvos viešosios bibliotekos ir jų padaliniai sudaro daugiau kaip pusę (53 proc.) Lietuvos bibliotekų tinklo ir yra labiausiai išplètotas šalyje kultūros įstaigų tinklas, veikiantis arčiausiai bendruomenių visos šalies teritorijoje ${ }^{10}$. Tad straipsnio objektas ir yra Lietuvos viešųjų bibliotekų potencialas ir prielaidos prisidèti prie žmogaus teisių igyvendinimo šaliai patiriant net dvi naujas krizes vienu metu. Straipsnio tikslas - apibendrinti Lietuvos viešųjų bibliotekų veiklą užtikrinant žmogaus teisių igyvendinimą COVID-19 pandemijos ir migrantų krizės sąlygomis, pateikti viešosioms bibliotekoms rekomendacijas, kaip prisidèti prie nūdienos krizių sukeltų problemų sprendimo šalyje. Siekiant užsibrežto tikslo, keliami šie uždaviniai: 1) apibrežti Lietuvos viešųjų bibliotekų veiklos kontekstą dviejų krizių akivaizdoje; 2) pateikti viešosios bibliotekos tipologinę charakteristiką, atskleidžiant viešosios bibliotekos socialinès sanglaudos funkciją; 3) pateikti empirinio tyrimo

Plačiau žr. Pilkūnè, D. Dẻl suintensyvejjusių nelegalios migracijos srautų paskelbta valstybès lygio ekstremali situacija. Delfi, BNS, 2021.07.02. Prieiga per internetą: https://www.delfi.lt/news/daily/lithuania/del-suintensyvejusiu-nelegalios-migracijos-srautu-paskelbta-valstybes-lygio-ekstremali-situacija.d?id=87621349. Žiūrèta 2021-09-10. İ šalị pateko daugiau kaip keturi tūkstančiai nelegalių migrantų. Politikai teigia, kad nè vienam iš jų politinis prieglobstis suteiktas nebus; net jei teisè gyventi Europos Sąjungoje ir būtų suteikta, dauguma migrantų neketina likti Lietuvoje, jų tikslas yra didžiosios Vakarų ir Šiaurès Europos ekonomikos Vokietija, Prancūzija, Švedija. Tad atrodytų, kad krizè yra tik politinè, laikina ir šiuo metu jau suvaldyta. Vis dèlto, praèjus keletui mènesių nuo nelegalios migracijos pradžios, migrantų skaičius, nors dalis jų ir sutiko grižži ị kilmės šalis, reikšmingai nesumažèjo. Net ir gerokai padidinus valstybès tarnautojų pajègas, sprendimai dẻl migrantų statuso ir likimo nepriimami ir negali būti priimami greitai. Ketvirtadalis ị Lietuvą naujai patekusių žmonių yra nepilnamečiai, dalis jų - mažamečiai ir kūdikiai. Yra ir migrantų šeimų didẻjimo tendencija; kai kurie jų kūdikiai gimẻ jau Lietuvoje. Artẻjant šaltajam sezonui, planuojama migrantus perkelti iš stovyklụ ì labiau pritaikytas gyventi patalpas. Nuo spalio mėnesio migrantų vaikai mokomi, pradedant nuo lietuvių kalbos. Visi šie faktai rodo, kad laikinumas gali tęstis metus ar keletą metų.

Plačiau žr. Labanauskas, L. Rasistiniai išpuoliai, neapykantos nusikaltimai ir incidentai prieš imigrantus Lietuvoje. Filosofija. Sociologija, 2020, t. 31, Nr. 4, p. 283-290.

Plačiau apie tai žr. Bružaitè, T. Migracija yra neišvengiama: pokalbis su dr. Egle Verseckaite-Grzeskowiak. Bernardinai.lt, 2021.07.26. Prieiga per internetą: https://www.bernardinai.lt/migracija-yra-neisvengiama-pokalbis-su-dr-egle-verseckaite-grzeskowiak/. Žiūrèta 2021-09-10.

9 Plačiau apie tai žr. Jaruševičiūtè, G. Navickienè: gavę prieglobsčio statusą, afganistaniečiai galès pasirinkti, ar likti Lietuvoje, ar ieškoti naujų galimybių. LRT.lt, 2021.08.26. Prieiga per internetą: https://www.lrt.lt/naujienos/lietuvoje/2/1476128/navickiene-gave-prieglobscio-statusa-afganistanieciai-gales-pasirinkti-ar-likti-lietuvoje-ar-ieskoti-nauju-galimybiu. Žiūrèta 2021-09-10.

10 Naujausias tyrimas rodo - viešosios bibliotekos gerina lankytojų gyvenimo kokybę. LNB.lt, 2020.01.30. Prieiga per internetą: https://www.lnb.lt/naujienos/5059-naujausias-tyrimas-rodo-viesosios-bibliotekos-gerina-lankytoju-gyvenimo-kokybe. Žiūrèta 2021-05-05. 
apie Lietuvos viešųjų bibliotekų potencialą prisidedant prie žmogaus teisių igyvendinimo dviejų krizių akivaizdoje rezultatus.

Sistemingų, kompleksinių tyrimų straipsnio tema Lietuvoje nèra. Esama darbų, apimančių tik vieną ar kitą šio tyrimo aspektą. Viešosios bibliotekos tipologinị savitumą, bibliotekų paslaugų teikimą imigrantams iš trečiųjų šalių išsamiai tyrinèjo užsienio ir Lietuvos mokslininkai. Tarptautinès bibliotekų asociacijos ir organizacijos yra pateikusios gairių dèl viešųjų bibliotekų veiklų ${ }^{11}$. Lietuvoje viešosios bibliotekos fenomeną nuodugniausiai analizavo ir pirmą kartą Šiaurès šalių viešųjų bibliotekų pavyzdžius Lietuvos bibliotekų bendruomenei pristate Audronė Glosienė su bendraautorèmis ${ }^{12}$. Gerąją Lietuvos ir užsienio viešųų bibliotekų patirtị tyrè Ramunė Petuchovaite $\dot{e}^{13}$. A. Glosienè mokslo studijoje „Kūrybiškumas ir socialinis kapitalas žinių visuomenèje: idejjų žemėlapis“ brěžè bibliotekininkystès kaip socialinio lauko ribas ${ }^{14}$. Bibliotekos sampratos, jos vaidmenų kaitos tinklaveikos visuomenejje problematiką daktaro disertacijoje analizavo Laura Juchnevič ${ }^{15}$. Nacionalinès bibliotekos autorių kolektyvas $2018 \mathrm{~m}$. parengè darbo su migrantais gaires bibliotekoms ${ }^{16}$.

Šiam straipsniui parengti buvo itin naudingas Liutauro Labanausko, analizuojančio rasistinio pobūdžio neapykantos incidentų patirtis prieš Lietuvoje gyvenančius imigrantus, tyrimas ${ }^{17}$, Monikos Frëjutės-Rakauskienès „pabėgèlių arba migracijos krizès“ vaizdavimo Lietuvos žiniasklaidoje 2015-2017 m. tyrimas ${ }^{18}$ ir 2013 m. vykdytas tyrimas, kuriame atskleidžiamos pabègèlių integracijos Lietuvoje galimybès ir problemos ${ }^{19}$.

COVID-19 pandemijos akivaizdoje Lietuvos mokslininkų bendruomenė atliktų tyrimų pagrindu pateike solidžius situacijos ir igytų patirčių vertinimus ${ }^{20}$. Analizuotas pandemijos poveikis ịvairioms visuomenès veiklos sritims, susiliečiančioms ir su bibliotekų veikla, informaciniu visuomenès aprūpinimu - pavyzdžiui, pandemijos ịtaka aukštojo mokslo plètrai, skubiai perejjus prie nuotolinio mokymo ir mokymosi ${ }^{21}$. Siekdami gauti grịžtamajji ryši apie nuotoliniu būdu teiktas paslaugas, tyrimus atlieka ir bibliotekų specialistai ${ }^{22}$.

Šios gairès pateiktos nuorodose nr. 1-4.

Glosienè, A.; Petuchovaitè, R.; Racevičiūtè, R. Viešoji biblioteka: tradicija ir modernumas. Vilnius: Žara, 1998.

3 Petuchovaitė, R. Viešuju biblioteku paslaugu bendruomenei plètra: sékmingos praktikos Lietuvoje ir tarptautiniu veiksmu studija. Vilniaus universiteto leidykla, 2004.

14 Žr. Glosienè, A. Kürybiškumas ir socialinis kapitalas žiniu visuomenèje: idëju žemélapis. Vilniaus universiteto leidykla, 2010, p. 89-117.

15 Juchnevič, L. Biblioteku vaidmenų kaita tinklaveikos visuomenëje: Lietuvos atvejis. Daktaro disertacija: socialiniai mokslai, komunikacija ir informacija (08 S). Vilnius: Vilniaus universitetas, 2016.

${ }_{16}$ Daugiakultūrio dialogo biblioteka: darbo su migrantais gairès / sudarytojos E. Dikavičienė, B. Dženkaitienè, D. Ivanovienė, E. Puskunigytė, A. Vaškevičienė, R. Zenevskienė. Vilnius: Lietuvos nacionalinė Martyno Mažvydo biblioteka, 2018. Prieiga per internetą: http://eia.libis.lt/show.php?item=daugiakulturinio_dia. Žiūrèta 2021-09-30.

17 Labanauskas, L. Rasistiniai išpuoliai, neapykantos nusikaltimai ir incidentai prieš imigrantus Lietuvoje. Filosofija. Sociologija, 2020, t. 31, Nr. 4, p. 283-290.

18 Frejjutè-Rakauskienè, M. Reali ar sukurta?: „pabègèlių krizès“vaizdavimas Lietuvos spaudos diskurse 2015-2017 metais. Informacijos mokslai, 2020, t. 88, p. 29-45.

19 Žr. Pabégèliu integracija Lietuvoje: dalyvavimas ir igalinimas: integracijos Lietuvoje suvokimas pagal amžiaus, lyties ir įvairovés aspektais grindžiama dalyvaujamaji metodą: $2013 \mathrm{~m}$. spalio-lapkričio mèn. Jungtinių Tautų vyriausiojo pabėgèlių reikalų komisaro biuras, 2014 m. rugsėjo mèn. Prieiga per internetą: https://www.refworld.org/cgi-bin/texis/vtx/rwmain/opendocpdf.pdf?reldoc $=y \& d o c i d=58 a 486 e f 1$. Žiūreta 2021-09-30.

20 Žr. visų pirma: Bortkevičiūtė, R.; Kalkytė, P.; Kuokštis, V.; Nakrošis, V.; Patkauskaitė-Tiuchtienè, I.; Vilpišauskas, R. Nuo greitu pergaliu prie skaudžiu pralaiméjimu: Lietuvos viešosios politikos atsakas j̣ COVID-19 pandemija ir šios krizés valdymas $2020 \mathrm{~m}$. Vilnius: Vilniaus universiteto leidykla, 2021; Telešiené, A.; Balžeikienė, A.; Budžyte, A.; Zolubienè, E. COVID-19 rizikos suvokimas ir socialiniai daugikliai Lietuvoje. Filosofija. Sociologija, 2021, t. 32, Nr. 2, p. 95-104; Genys, D.; Imbrasaite, J. Pilietinés saviraiškos ir valstybinio paternalizmo konfigūracijos COVID-19 pandemijos laikotarpiu. Darbai ir dienos, 2021, t. 75, p. 113-126.

21 Žr., pavyzdžiui: Sultanova, L.; Milto, L.; Zheludenko, M. The Impact of the COVID-19 Pandemic on the Development of Higher Education. Acta Paedagogica Vilnensia, 2021, t. 46, p. 132-147.

22 Žr., pavyzdžiui: Alytaus Jurgio Kunčino viešosios bibliotekos lankytoju nuomonès tyrimas apie mokslines paslaugas karantino metu I Parengė I. Lukoševičienè. Prieiga per internetą: http://www.alytus.mvb.lt/images/pdf/apklausos/2020nuotolines_paslaugos.pdf. Žiūrèta 2021-09-07. 
Pasaulinių krizių akivaizdoje igyvendinti žmogaus teises tampa iššŭkiu ${ }^{23}$. Žmogaus teisių stebėseną Lietuvoje vykdo Žmogaus teisių stebejimo institutas, kurio parengta 2018-2019 m. stebėsenos ataskaita ${ }^{24}$ yra jau dešimta. Remiantis šiomis ataskaitomis ir tyrejjų ižvalgomis ${ }^{25}$, konstatuotina: igyja pagreiț žmogaus teisių nuvertėjimo tendencija, kuri galimai dar labiau aštrès dẻl Lietuvos patiriamų krizių itakos.

Lietuvos visuomenès vertybinių nuostatų kaitos tyrimai rodo, kad Lietuvą galima vadinti šalimi, turinčia vieną silpniausių pilietinių visuomenių Europoje ${ }^{26}$. Lietuvos visuomenė, remiantis gyventojų pilietinėmis nuostatomis, įskaitant ir toleranciją kitos gyvensenos žmonèms, yra pažeista ne tik politinio, bet ir socialinio susvetimejjimo. Kaip rodo tyrimai, pastaraisiais dešimtmečiais Vakarų pasaulyje pastebimas vertybinis virsmas - pereinama nuo materialiųjų (saugumo, išlikimo) prie postmaterialiųjų (savirealizacijos) vertybių dominavimo; to priežastis, mokslininkų nuomone, buvo ilgalaikis ekonominis augimas ${ }^{27}$. Šiame kontekste pažymima, kad Lietuvos gyventojų vertybinès nuostatos nėra aiškiai susiformavusios ir konsoliduotos, jų kaita yra nenuosekli ir labai stipriai reaguojanti ị momentines situacijas - ekonomines ir politines aplinkybes ${ }^{28}$.

Šio teksto pagrindinę empirinę šaltinių bazę sudaro straipsnio autorès $2020 \mathrm{~m}$. kovo mėnesio pabaigoje atlikto empirinio tyrimo duomenys ${ }^{29}$. Juos papildo kitas šio straipsnio autorès empirinis tyrimas, atliktas $2021 \mathrm{~m}$. gegužès mènesị (prieš pat prasidedant nelegalios migracijos bangai ${ }^{30}$ ). Imigracijos ¡ Lietuvą situacija $2021 \mathrm{~m}$. vasarą dramatiškai pakito, tad straipsnyje pasitelkiama ir pagrindiniuose šalies žiniasklaidos portaluose delfi.lt, lrytas.lt, lrt.lt skelbiama informacija. Medijose skelbiamų žinių srautas Lietuvos patiriamų krizių temomis yra labai intensyvus. Kiekvieną dieną paskelbiama naujų publikacijų, interviu, diskusijų medžiagos. Straipsnyje viešojo diskurso šaltinių atranka atliekama ne tik pasitelkus temini kriterijų (t. y. naudojant tiesiogiai su straipsnio temomis susijusias, faktinę informaciją pateikiančias publikacijas), bet ir atsižvelgiant ị šiose publikacijose pateikiamo turinio objektyvumą ir patikimumąą. Atliekant tyrimą taip pat naudota oficialių šaltinių, oficiali statistinè ir kita informacija. Galiausiai straipsnyje medžiaga gretinama ir lyginama su Lietuvos ir užsienio dalyko moksline literatūra.

COVID-19 and Human Rights: We are all in this together. United Nations, April 2020. Prieiga per internetą: https://www.un.org/victimsofterrorism/sites/www.un.org.victimsofterrorism/files/un_-_human_rights_and_covid_april_2020.pdf. Žiūrèta 2021-09-15.

24 Žmogaus teisés Lietuvoje 2018-2019: apžvalga / redakcinè grupė: G. Jurevičiūtė, M. Adutavičiūtė, U. Grigaitė, E. Leonaitė, D. Pūras. Vilnius: Žmogaus teisių stebejjimo institutas, 2020.

25 Žr., pavyzdžiui: Lahayne, H. Žmogaus teisių infliacija. Bernardinai.lt, 2020.09.28. Prieiga per internetą: https://www.bernardinai.lt/ zmogaus-teisiu-infliacija/. Žiūrèta 2021-08-21; Lahayne, H. Laisvẻ be epitetų: Friedrichas Hayekas ir kelias iš pandemijos vergovès. Naujasis Židinys-Aidai, 2021, Nr. 6, p. 13-18.

26 Žr. Žiliukaitè, R.; Poviliūnas, A.; Savicka, A. Lietuvos visuomenes vertybių kaita per dvidešimt nepriklausomybès metų. Vilniaus universitetas, 2016.

Plačiau žr. Norkus, Z. Ar galime gyventi geriau? Velfarizmas ir jo alternatyvos. Politologija, 2004, t. 4, Nr. 36, p. $29-33$.

Žr. Žiliukaitè, R.; Poviliūnas, A.; Savicka, A. Lietuvos visuomenès vertybiu kaita per dvidešimt nepriklausomybès metu, p. $209-211$.

Januševičienè, R. Lietuvos viešosios bibliotekos pirmosiomis karantino savaitemis. Tarp knygų, 2020, balandis, p. 13-15.

Lietuvos viešosios bibliotekos aktyviai prisideda igyvendinant Žmogaus teises: tyrimo ataskaita / Parenge R. Januševičienė. Lietuvos bibliotekininkų draugija, 2021 m. 5 p. [Rankraštis].

31 Remiamasi mokslininkų, žinomų politikos apžvalgininkų straipsniais, interviu su politikais: Mažeikis, G. Beveidžiai pabėgèliai ir hibridinis karas. LRT.lt, 2021.07.08. Prieiga per internetą: https://www.lrt.lt/naujienos/nuomones/3/1446484/gintautas-mazeikis-beveidziai-pabegeliai-ir-hibridinis-karas. Žiūrèta 2021-08-29; Mažeikis, G. İniršis ir beveidiškumas: migrantų krizè. LRT.lt, 2021.07.29. Prieiga per internetą: https://www.lrt.lt/naujienos/nuomones/3/1458802/gintautas-mazeikis-inirsis-ir-beveidiskumas-migrantu-krize. Žiūretta 2021-08-29; Šakaliené, D. Kas valdo Europą: žmonių kontrabandininkai ar ịstatymai? LRT.lt, 2021.09.20. Prieiga per internetą: https://www.lrt.lt/naujienos/pozicija/679/1499817/dovile-sakaliene-kas-valdo-europa-zmoniu-kontrabandininkai-ar-istatymai. Žiūrèta 2021-09-21; Bružaitė, T. Migracija yra neišvengiama: pokalbis su dr. Egle Verseckaite-Grzeskowiak. Bernardinai.lt, 2021.07.26. Prieiga per internetą: https://www.bernardinai.lt/migracija-yra-neisvengiama-pokalbis-su-dr-egle-verseckaite-grzeskowiak/.Žiūrèta 2021-09-10; Musnickas, R. „ES turi sukrusti ir suprasti“ - krizés akivaizdoje Linkevičius palaiko griežtesnę migracijos politiką. LRT.lt, 2021.08.24. Prieiga per internetą: https://www.lrt.lt/naujienos/pasaulyje/6/1475213/es-turi-sukrusti-ir-suprasti-krizes-akivaizdoje-linkevicius-palaiko-grieztesne-migracijos-politika. Žiūrèta 2021-08-24; Ilkevičiūté, J. Lietuvos ambasadorius ES: kaip pavyko sustabdyti Irako skrydžius ir kodèl Briuselis nefinansuoja sienos statybos. LRT. lt, 2021.08.23. Prieiga per internetą: https://www.lrt.lt/naujienos/pasaulyje/6/1472240/lietuvos-ambasadorius-es-kaip-pavyko-sustabdyti-irako-skrydzius-ir-kodel-briuselis-nefinansuoja-sienos-statybos. Žiūrèta 2021-08-23. 
Straipsnis sudarytas iš trijų dalių. Pirmoje dalyje demesys sutelkiamas ị Lietuvos viešụjų bibliotekų veiklos užtikrinant žmogaus teisių igyvendinimą kontekstą dviejų krizių akivaizdoje. Ši dalis skirta problemai konceptualiai pagrịsti. Antroje dalyje pateikiama viešosios bibliotekos tipologine charakteristika, atskleidžianti jos socialinès sanglaudos funkciją. Trečia straipsnio dalis - empirinio tyrimo apie Lietuvos viešujų bibliotekų potencialą prisidedant prie žmogaus teisių igyvendinimo krizių akivaizdoje pristatymas ir rezultatų pateikimas. Šios dalies tikslingumas grindžiamas siekiu užčiuopti realų dviejų krizių poveikị viešosioms bibliotekoms ir atskleisti jų atsaką užtikrinant žmogaus teisių ịgyvendinimą. Straipsnio pabaigoje pateikiamos išvados ir rekomendacijos.

\section{1. Žmogaus teisių igyvendinimo dilemos krizių akivaizdoje: situacijos apžvalga}

2020-2021 m. ịeis ị pasaulio istoriją kaip laikotarpis, kai ištiko net kelios visuotinès krizès: COVID-19 pandemija, paveikusi daugelio pasaulio šalių ekonomiką, sveikatos apsaugos sistemą, visuomenès fizinę ir psichikos sveikatą, švietimo kokybę, ir politinè krizė, turèsianti ilgalaikių padarinių daugeliui pasaulio šalių.

COVID-19 pandemija privertè šalis įvesti ekstremaliąją padètị siekiant gelbèti gyvybes. Šioje situacijoje jos neturi pasirinkimo, tik naudoti neịprastas priemones - apriboti visuomenès laisves, suvaržyti judėjimą. Siekiama „neperdeginti“ sveikatos apsaugos sistemų ir užtikrinti jų funkcionavimą. Sveikatos apsaugos sistemos krizè (kai ligoninèse ima trūkti vietų pandeminiams ligoniams, stigti medicinos personalo, įrangos ir dèl to tenka riboti ar nutraukti planines medicinos paslaugas) labai greitai tampa ekonomikos ir socialine krize, dèl kurios mažiausiai apsaugotos visuomenès grupès tampa dar pažeidžiamesnès ${ }^{32}$.

COVID-19 ir kultūros sektorius. Ilgalaikių 2020 m. ir ypač $2021 \mathrm{~m}$. karantinų padariniai, nežinomybè ir būtinybè planuoti veiklas ir veikti naujos realybės sąlygomis sunkina vyriausybių ir valstybès institucijų veiklą. Dèl nepasitenkinimo pandemijos valdymo priemonėmis kyla dalies visuomenės pasipiktinimas ir protestai, tai dar labiau skatina kuriama ir socialiniuose tinkluose, taip pat interneto kanaluose skleidžiama melaginga informacija apie vakcinavimo žalą. Tarp Lietuvos Respublikos Vyriausybès nuo $2021 \mathrm{~m}$. rugsejo $13 \mathrm{~d}$. ịvestų pandemijos valdymo priemonių dominuoja galimybiu pasas, kurị turintiems asmenims prieinamos kontaktiniu būdu teikiamos paslaugos ${ }^{33}$. Jis suteikiamas nuo COVID-19 pasiskiepijusiems ar šia liga persirgusiems asmenims. Galimybių pasas pozicionuojamas ir kaip bilietas ị visavertị kultūrinį gyvenimą; tikimasi, kad kultūros ịstaigos nebus priverstos vèl vegetuoti griežto ir ilgo karantino sąlygomis. Bibliotekoms ir muziejams, kaip įstaigoms, teikiančioms gyvybiškai svarbias informacijos paslaugas ir galimybes pažinti nacionalinį ir pasaulio paveldą, sudaroma išimtis - laikantis saugumo reikalavimų leidžiama teikti paslaugas visiems lankytojams, neatsižvelgiant $\mathfrak{i}$ jų apsisprendimą skiepytis ${ }^{34}$. Tačiau daugelis viešųjų paslaugų galimybių paso neturintiems asmenims tampa neprieinamos. Daliai visuomenès narių, turinčių teisę i galimybių pasą, sudètinga jị issigyti. Ši problema ypač aktuali senjorams, nesinaudojantiems išmaniaisiais telefonais, kompiuteriais, internetu.

Imigrantu srautu padidèjimas. 2021 m. gegužès-liepos mėnesiais Lietuvos Respublika susidūrè su neịprastai dideliais neteisètų migrantų, bandančių patekti ị Lietuvą iš Baltarusijos, srautais. $2021 \mathrm{~m}$. rugpjūčio 17 d. vykusiame Europos Sąungos (ES) nepaprastajame vidaus reikalų ministrų susitikime Lietuva pabrèžè, kad tai hibridinė agresija, visai kitokia nei migracijos bangos, su kuriomis buvo susidūrusios

Žr. COVID-19 and Human Rights: We are all in this together.

3 Patvirtintos naujos pandemijos valdymo priemonès. Korona stop, 2021.08.11. Prieiga per internetą: https://koronastop.lrv.lt/lt/ naujienos/patvirtintos-naujos-pandemijos-valdymo-priemones. Žiūrèta 2021-08-23.

34 Kultūros ministras S. Kairys: artèjantis naujas kultūros sezonas taps laisvesnis ir intensyvesnis. Lietuvos Respublikos kultūros ministerija, 2021.08.17. Prieiga per internetą: lrkm.lrv.lt/lt/naujienos/kulturos-ministras-s-kairys-artejantis-naujas-kulturos-sezonas-taps-laisvesnis-ir-intensyvesnis. Žiūrèta 2021-08-23. 
ES šalys ${ }^{35}$. Lietuvos statistikos departamento $2021 \mathrm{~m}$. rugpjūčio $21 \mathrm{~d}$. duomenimis, mūsų šalyje buvo 4137 neteisèti migrantai, dauguma jų (2800 asmenys) - Irako piliečiai. 26 proc. migrantų iš Afganistano yra nepilnamečiai ${ }^{36} .160$ vaikų mokymas vyksta nuo $2021 \mathrm{~m}$. spalio $4 \mathrm{~d} \cdot{ }^{37}$

Dèl politinès situacijos Afganistane Lietuvos Respublikos Vyriausybẻ nutarè ị mūsų šalị perkelti ir čia apgyvendinti iki 200 šios šalies piliečių ${ }^{38} .2021 \mathrm{~m}$. rugpjūčio 26 d. jie pasiekè Lietuvos Respublikos teritoriją. Suteiktas politinio pabėgèlio statusas leis jiems apsigyventi ir dirbti ir kitose ES šalyse, tačiau tiketina, kad dalis Afganistano politinių pabėgèlių liks Lietuvoje. Europos šalių praktika ir patirtys rodo, kad migrantai šalyse (migrantų centruose) gali gyventi metų metus ir jiems reikia darbo, mokyklų, sveikatos paslaugų ${ }^{39}$.

Žmogaus teisių iggyvendinimas krizių laikotarpiu. Būtinybè kurti nauja imigracijos politiką. Žmonès naudojami kaip politinio spaudimo priemonè, ir tai mūsų šaliai yra nauja patirtis. Žmogaus teisių stebëjimo institutas 2018-2019 m. (t. y. ikikrizinio laikotarpio) apžvalgoje pastebi, kad žmogaus teisių problematika atsidūrè politinės darbotvarkès paraštėse. Ištikus krizėms ar nelaimėms, politinėse darbotvarkèse konstatuojama: kol situacija bus normalizuota, žmogaus teisės gali palaukti ${ }^{40}$. Holgerio Lahayneo įžvalgos dar konkretesnès: kai kurios žmogaus teisès jau tapo daugiau ar mažiau utopiniais idealais. Klasikinès arba „pirmosios kartos“ Visuotineje žmogaus teisių deklaracijoje (1948) ${ }^{41}$ išdèstytos (iki 21 straipsnio) žmogaus teisès - tai politinès teisès, kurios apima gyvybės ir nuosavybès apsaugą, lygybę prieš įstatymą, judejjimo, žodžio, religijos ir susirinkimų laisvę. Vakarų valstybių konstitucijos yra paremtos šia pagrindinių teisių teorija. XX a. atsirado teisių „antroji karta“ - ekonominès, socialinès ir kultūrinès teisès. Tai teisès ị tam tikrą gerovès lygị, darbą, maistą, būstą, socialinę apsaugą, teisè dalyvauti kultūriniame gyvenime. Yra ir teisių „trečioji karta“, susijusi su kolektyvinėmis tautų teisèmis. Bet, pasak H. Lahayne’o, kur rasti tokią visuomenę, kuri visiškai iggvendintų teisę ị taiką, švarią aplinką, orų atlyginimą ir t. t.? ${ }^{42}$

I Lietuvą $2021 \mathrm{~m}$. per trumpą laiką patekusių politinių pabègèlių, neteisètų migrantų skaičius viršijo ankstesnius, kontroliuojamus imigracijos srautus. Iš Azijos ir Afrikos šalių atvykę migrantai apgyvendinami Lietuvos miesteliuose ir gyvenvietėse. Tai kelia vietinių gyventojų nepasitenkinimą, jie jaučiasi nesaugūs. Ryškẻja kultūriniai skirtumai, dialogo galimybes sunkina kalbų ir kultūrinių skirtumų barjerai. Kyla priešprieša tarp reikalavimų užtikrinti migrantų žmogaus teises ir Lietuvos visuomenès pasipiktinimo neteisètai ị šalị patekusiųjų elgsena, pozicija, retorika ${ }^{43}$. Šị teiginị iliustruoja $2021 \mathrm{~m}$. vasarą Lietuvos Respublikos valdžios institucijų priimti migrantų krizès valdymo sprendimai, sulaukiantys kritikos dèl žmogaus teisių apribojimo. Tokia paradoksali situacija, vykstant hibridinei agresijai, liudija apie naują būtinybę kurti Europos Sąjungos migracijos politiką ${ }^{44}$.

Ilkevičiūtè, J. Lietuvos ambasadorius ES: kaip pavyko sustabdyti Irako skrydžius ir kodèl Briuselis nefinansuoja sienos statybos. LRT. lt, 2021.08.23. Prieiga per internetą: https://www.lrt.lt/naujienos/pasaulyje/6/1472240/lietuvos-ambasadorius-es-kaip-pavyko-sustabdyti-irako-skrydzius-ir-kodel-briuselis-nefinansuoja-sienos-statybos. Žiūrèta 2021-08-23.

36 Neteisetos migracijos stebėsena. Lietuvos statistikos departamentas. Prieiga per internetą: https://s-osp-sdg.maps.arcgis.com/apps/ dashboards/9b0a008b1fff41a88c5efcc61a876be2. Žiūrèta 2021-08-23.

37 Žr. Jačauskas, I. Lietuvių kalbos pamokų rudenị sulauks per 160 migrantų vaikų, jų skaičius gali didèti. LRT.lt, 2021.08.29. Prieiga per internetą: https://www.lrt.lt/naujienos/lietuvoje/2/1479339/lietuviu-kalbos-pamoku-rudeni-sulauks-per-160-migrantu-vaikuju-skaicius-gali-dideti. Žiūrèta 2020-08-30.

38 Plačiau žr. Pankūnas, G. Vyriausybė nutarè: Lietuva priims ir apgyvendins iki 200 Afganistano piliečių. LRT.lt, 2021.08.25. Prieiga per internetą: lrt.lt/naujienos/lietuvoje/2/1475626/vyriausybe-nutare-lietuva-priims-ir-apgyvendins-iki-200-afganistano-pilieciu. Žiūrèta 2021-08-25.

39 Plačiau apie tai žr. Mažeikis, G. Beveidžiai pabegèliai ir hibridinis karas; Šakalienė, D. Kas valdo Europą: žmoniu kontrabandininkai ar istatymai?

40 Plačiau žr. Žmogaus teisès Lietuvoje 2018-2019: apžvalga.

41 Visuotine žmogaus teisių deklaracija. Prieiga per internetą: urm.lt/uploads/default/documents/uzienio_politika/zmogaus_teises/ Visuotine_zmogaus_teisiu_deklaracija.pdf. Žiūrèta 2021-08-26.

2 Plačiau žr. Lahayne, H. Žmogaus teisių infliacija.

43 Plačiau apie tai žr. Mažeikis, G. Iniršis ir beveidiškumas: migrantų krizè.

44 Plg.: Musnickas, R. „ES turi sukrusti ir suprasti“ - krizés akivaizdoje Linkevičius palaiko griežtesnę migracijos politiką. 
Imigrantu integracijos modeliai ir galimybès. Pati migracija yra vertinama kaip neišvengiamas procesas, natūralus reiškinys, nulemtas šalių ekonominių ir socialinių skirtumų ${ }^{45}$. Šalys naudoja skirtingus imigrantų integracijos modelius - asimiliacijos, integracijos, daugiakultūrès visuomenès. Patiriami iššǔkiai verčia valstybes siekti bendro pragmatiško problemų sprendimo, neatsisakant universalios politikos, pagrịstos bendros kalbos praktika, pagarba bendriems politiniams principams ir vienodoms galimybèms gauti teises, būstą ir darbą ${ }^{46}$. Tyrimais nustatyta, kad probleminiai imigrantų integracijos aspektai yra šie:

- kalbos mokymasis,

- užimtumas ir darbo paieška,

- būstas,

- socialinių ryšių su daugumos visuomene užmezgimas ir plètojimas,

- daugumos visuomenès nuostatos ${ }^{47}$.

Migracijos ị ES šalis situacija akivaizdžiai pakito. Didẻja žmonių kontrabandos mastas, migrantų srautai naudojami kaip politinio spaudimo priemonè, kyla grèsmè, kad dèl klimato šiltėjimo Vidurinių Rytų valstybes ištiks ekologinè katastrofa ir migrantų srautai pajudès į ES šalis - dẻl viso šito reikia peržiūrèti pasenusį ir atgyvenusį migracijos politikos modelị ir kurti naują strategiją. Europos šalių (turinčių didesnę neteisètos imigracijos patirtị) visuomenès nuostatos dèl migrantų yra neigiamos. Taip yra dèl to, kad nebeatitinkantis realybès integracijos valdymo modelis ES šalyse sukuria prielaidas atvykèliams ne tik naudotis šalių socialinès apsaugos sistemų teikiamomis galimybėmis, bet ir kurti tose šalyse savas taisykles ${ }^{48}$. Lietuva nebuvo pasiruošusi nelegalių migrantų srautams. Valdžios institucijų priimami sprendimai - tiek apgręžti migrantus, neileisti jų i šalies ir ES teritoriją, tiek apgyvendinti juos tokiomis sąlygomis, kokias gali suteikti valstybė, - sulaukia skundų dèl žmogaus teisių nuostatų nesilaikymo. Kita vertus, Lietuvos visuomenė priešiškai vertina migrantų išlaikymą mūsų šalyje ir pageidautų, kad jie būtų kuo greičiau išsiųsti ị kilmès šalis. To padarinys - visuomene skyla ị priešingas nuomones turinčių žmonių stovyklas (COVID-19 valdymo priemonių palaikytojus ir prieš tas priemones, pirmiausia vakcinavimą, valdžios raginimus skiepytis nusiteikusius žmones; vertybinių nuostatų žmogaus teisių požiūriu puoselètojus ir prieš nelegalius migrantus nusiteikusius asmenis). Trūksta švietimo, patikimos informacijos, kuri galetų šią ịtampą sumažinti. Pagal tipologines apibrežtis viešosios bibliotekos (skirtos paslaugoms visoms visuomenès grupėms teikti, kuriančios ir puoselëjančios bendruomenes) galètu prisidèti prie ịtampos ir visuomenès susipriešinimo mažinimo.

Krizių patirtys leidžia pateikti kai kurias įžvalgas.

Siekiant suvaldyti COVID-19 pandemijos krizes, būtina:

- teikti kuo daugiau patikimos, aiškios, argumentais ir ịrodymais pagrịstos, visoms visuomenès grupèms suprantamos informacijos apie krizès valdymo situaciją ir priemones;

- teikti informaciją laiku, patogiais ir pasiekiamais, bendruomenès naudojamais kanalais;

- sudaryti interneto prieigą informacijai gauti;

- efektyviausiai panaudoti valstybès turimus institucijų informacinius išteklius, informacijos sklaidos ir komunikacijos kanalus;

- aiškiai ịvardyti įstaigas, kurios gali suteikti ịvairią pagalbą; gyventojai turi aiškiai žinoti, kur kreiptis pagalbos;

- teikti aiškią ir konkrečią informaciją apie priimtas priemones, pavyzdžiui, kur ir kada (kokiomis darbo valandomis) galima atsiimti galimybių pasą.

\footnotetext{
Žr. Bružaitė, T. Migracija yra neišvengiama: pokalbis su dr. Egle Verseckaite-Grzeskowiak.

46 Plačiau apie tai žr. Choquet, S. Models of Integration in Europe. European Issue, 2017, No. 449, 30th October, p. 1-8. Prieiga per internetą: https://www.robert-schuman.eu/en/european-issues/0449-models-of-integration-in-europe. Žiūrèta 2021-08-27.

47 Plačiau žr. Žibas, K.; Platačiūtè, V. Migrantų integracija ir migracijos tinklai Lietuvoje: nuo teorinių veiksnių iki empirinių duomenų. Oikos: lietuviu migracijos ir diasporos studijos, Nr. 2 (18), 2014, p. 7-22.

48 Plačiau apie tai žr. Šakalienè, D. Kas valdo Europą: žmonių kontrabandininkai ar įstatymai?
} 
Migracijos krizès kontekste siūlytinos šios jos suvaldymo gairès (priemonès):

- dabartinis pasenęs ir nebeatitinkantis realybès migracijos valdymo modelis turètų būti keičiamas. Jungtinių Tautų, ES institucijos ir šalys turètų siekti, kad būtų pertvarkyta nebeveiksminga teisinė sistema migracijos klausimais;

- siekiant užkirsti kelią ksenofobijai, rasizmui, nepakantumui Lietuvoje, siūloma užtikrinti kryptingesnį bendruomenių informuotumą apie migrantų kilmę, poreikius, gebẻjimus.

Bendruomenems rekomenduotina:

- naudoti visuomenès švietimo priemones situacijai gerinti;

- rengti informacines kampanijas bendruomenių informuotumui didinti, taip pat bendrus projektus ir renginius migrantams, supažindinančius su Lietuvos visuomene ir kultūra.

\section{Viešosios bibliotekos misija - socialinès sanglaudos puoselèjimas}

Viešoji biblioteka yra organizacija, ịsteigta, remiama ir finansuojama bendruomenès per vietos, regiono valdžią ar nacionalinę vyriausybę, suteikianti informacijos, žinių, išteklių ịvairiomis formomis prieigą ir skatinanti mokytis visą gyvenimą. Viešosios bibliotekos yra demokratinès institucijos, aptarnaujančios visus $\mathfrak{i}$ jas besikreipiančius visuomenès narius, nediskriminuojant pagal jokius (tautinius, religinius, amžiaus, lyties, kalbos, negalios) požymius. Pagrindinis viešosios bibliotekos tikslas yra įvairiomis formomis teikti išteklius ir paslaugas visuomenès, asmenų ir grupių švietimo, informaciniams ir asmeninio tobulèjimo poreikiams tenkinti, įskaitant laisvalaikị ir poilsị. Šios nuostatos apibrèžtos 1994 m. IFLA / UNESCO viešųjų bibliotekų manifeste ${ }^{49}$. Jis greitai tapo pripažintas kaip svarbus viešųjų bibliotekų pozicijos pareiškimas, buvo išverstas ị daugiau kaip dvidešimt kalbų ir tapo strateginiu viešuoju dokumentu, kurio nuostatomis veiklą grindžia viso pasaulio viešosios bibliotekos. $2006 \mathrm{~m}$. IFLA paskelbẻ Daugiakultūrès bibliotekos manifestą, kuriame pabrěžiama, jog visų tipų bibliotekos tarptautiniu, nacionaliniu ir vietos lygmenimis turi atspindèti, remti ir skatinti kultūrų ir kalbų įvairovę ir prisidèti prie tarpkultūrinio dialogo ir aktyvaus pilietiškumo skatinimo ${ }^{50}$.

Teikdamos paslaugas ịvairioms bendruomenèms, bibliotekos veikia kaip mokymosi, kultūros ir informacijos centrai. Pagal Daugiakultūrès bibliotekos manifestą, bibliotekos privalo:

- aptarnauti visus bendruomenès narius, nediskriminuodamos kultūrinio ir kalbinio paveldo pagrindu;

- teikti informaciją tinkamomis kalbomis ir rašmenimis;

- samdyti darbuotojus, kurie atspindètų bendruomenès sudètí, mokètų dirbti su įvairiomis bendruomenemis ir jas aptarnautų.

Šiame kontekste bibliotekų teikiamos informacijos paslaugos suvokiamos ir kaip bendrosios (skirtos visiems vartotojams), ir kaip specialiosios (skirtos mažiau galimybių turinčioms kultūrinėms ir kalbinèms grupèms).

Socialinė sanglauda apima pasitikejimą, toleranciją ir solidarumą ${ }^{51}$. Lietuvos visuomenè pagal gyventojų pilietines nuostatas, tarp jų ir toleranciją kitos gyvensenos žmonėms, vertintina kaip smarkiai pažeista ne tik politinio, bet ir socialinio susvetimèjimo ${ }^{52}$. Socialinių struktūrų pokyčių kontekste

IFLA/UNESCO Public Library Manifesto 1994. Prieiga per internetą: https://www.ifla.org/node/91700. Žiūrèta 2021-09-22. Taip pat žr. Glosienė, A.; Petuchovaitė, R.; Racevičiūtè, R. Viešoji biblioteka: tradicija ir modernumas; Masevičienė, A. Daugiakultūrè kompetencija. In: Daugiakultūriškumas: inovatoriai ir ugdytojai bibliotekose: mokomasis paketas bibliotekoms / Erasmus+. Prieiga per internetą: https:/ec.europa.eu/programmes/erasmus-plus/project-result-content/693ac91a-037e-4d0a-aa8a-4d5ac18b3abd/ O3_Educational\%20materials_LIT.pdf. Žiūrèta 2021-09-24.

50 IFLA/UNESCO Multicultural Library Manifesto: The Multicultural Library - A Gateway to a Cultural Diverse Society in Dialogue. International Federation of Library Associations and Institutions (IFLANET), 2006. Prieiga per internetą: http://archive.ifla.org/VII/ s32/pub/MulticulturalLibraryManifesto.pdf. Žiūrèta 2021-08-27.

51 Žr. Žiliukaite, R.; Poviliūnas, A.; Savicka, A. Lietuvos visuomenès vertybiu kaita per dvidešimt nepriklausomybès metų, p. 197.

52 Žr. ibidem, p. 217 
bibliotekos tampa orientuotos mažinti socialinę atskirtị - jos suteikia galimybę visuomenei naudotis paslaugomis ir produktais, neatsižvelgdamos ị asmenų ar jų grupių socialinị statusą ${ }^{53}$. Lietuvos Respublikos kultūros ministro 2016 m. patvirtintose Biblioteku plètros strateginese kryptyse 2016-2022 metams kaip pagrindinès bibliotekų vertybès taip pat akcentuojama laisva prieiga visiems visuomenès nariams, atvirumas dialogui, bendruomeniškumas ${ }^{54}$.

Beje, daugiakultūrès bibliotekos idèjos Lietuvoje skleidžiamos jau per 30 metų. Mūsų šalies bibliotekų specialistai, aukštųjų mokyklų dėstytojai sėmèsi patirties daugiausia iš Skandinavijos bibliotekų, kūrusių paslaugas imigrantams dešimtmečiais anksčiau už Lietuvą. Patirties peremimas ir sklaida daugiausia vyksta tarptautinių konferencijų, stažuočių, bendradarbiavimo ịvairios projektinès veiklos pagrindu. Apibendrinus šias iš Suomijos gautas patirtis, išskirtinos šios viešųų bibliotekų darbo su migrantais ir pabègèliais kryptys:

- literatūros gimtąja kalba kaupimas ir skolinimas (skaitytojams; bibliotekų tinklui per tarpbibliotekinį abonementą); Suomijos pavyzdys - literatūros daugiau kaip 80 kalbų (turkų, arabų, kinų, vietnamiečių, kurdų, tajų ir kt.) komplektavimas;

- vaikams, jaunimui ir suaugusiesiems skirtų kolekcijų ịvairiomis kalbomis (knygų, periodinių leidinių, garso ir vaizdo dokumentų, elektroninių knygų) komplektavimas;

- dèmesys ankstyvajam ugdymui ir integracijai: bibliotekų pagalba ruošiant pamokas, rekomenduojamos literatūros sąrašai;

- valstybinès kalbos (kalbų) ir anglų kalbos kursai migrantams, bibliotekose dirbantys vertëjai, viešųjų bibliotekų bukletai įvairiomis kalbomis;

- nemokamas internetas, dokumentų skenavimas;

- mokymai, kaip naudotis šalies elektroninèmis sistemomis, konsultacijos, viešųjų bibliotekų darbuotojų pagalba pildant ịvairius dokumentus;

- kitataučių savanorių pagalba;

- dalyvavimas renginiuose ${ }^{55}$.

2017-2018 m. Nacionalinė biblioteka igyvendino Švietimo mainų paramos fondo programos „Erasmus+" lěšomis remiamą projektą „Tarpkultūrinis ir informacinis migrantų švietimas - personalo kompetencijų ugdymas", kurio tikslas buvo per darbo stebëjimo vizitus Skandinavijos šalių bibliotekose igytą patirti pritaikyti Nacionalinèje ir Vilniaus regiono viešosiose bibliotekose (Vilniaus apskrities Adomo Mickevičiaus viešojoje ir Švenčionių rajono savivaldybės viešojoje bibliotekoje), stiprinti jų kompetencijas ir igūdžius dirbant su migrantais ir pabègèliais ir skatinant juos mokytis visą gyvenimą ${ }^{56}$.

Užsienio šaliu viešuju biblioteku veikla, prisidedant prie imigrantu integracijos procesų. ALA vertina viešąsias bibliotekas kaip patikimą šaltinị naujiesiems amerikiečiams ịgyti žinių ir ịgūdžių gyventi šalyje. Imigracijos temoms kylant i viešojo diskurso prioritetus, ALA išleido gaires viešosioms bibliotekoms. Ataskaita „Bibliotekų programos ir naujieji amerikiečiai“ yra šešių mėnesių trukmės projekto $(2018 \mathrm{~m}$.) mokslinių tyrimų rezultatas. Projekte dalyvavo ALA, viešosios bibliotekos ir organizacijos partnerès. Ataskaitoje pateikiamos rekomendacijos viešosioms bibliotekoms:

- bendruomenès poreikių tyrimai;

- partnerystè su bendruomeninėmis organizacijomis;

Plačiau žr. Juchnevič, L. Biblioteku vaidmenu kaita tinklaveikos visuomeneje: Lietuvos atvejis.

Biblioteku plètros strategines kryptys 2016-2022 metams / Patvirtinta Lietuvos Respublikos kultūros ministro 2016 m. balandžio 29 d. ịsakymu Nr. IV-344. Prieiga per internetą: https://lrkm.lrv.lt/uploads/lrkm/documents/files/Biblioteku\%20pletros\%20kryptys.pdf. Žiūreta 2021-08-27.

55 Plačiau apie lietuvių bibliotekininkų patirtis ir bendradarbiavimą su Suomijos bibliotekomis, žr. Pažintis su novatoriška Suomijos biblioteku patirtimi imigrantu ir pabégéliu srityse. Lietuvos nacionalinė Martyno Mažvydo biblioteka, 2018.04.09. Prieiga per internetą: lnb.lt/naujienos/3034-pazintis-su-novatoriska-suomijos-biblioteku-patirtimi-imigrantu-ir-pabegeliu-srityse. Žiūrèta 2021-08-21.

56 Plačiau apie projektą, žr. Tarpkultūrinis ir informacinis migrantų švietimas - personalo kompetencijų ugdymas. Lietuvos nacionalinè Martyno Mažvydo biblioteka. Prieiga per internetą: nb.lt/apie-biblioteka/veiklos-sritys/programos-ir-projektai/kvalifikacijos-kelimas-mokymai/tarpkulturinis-ir-informacinis-migrantu-svietimas-personalo-kompetenciju-ugdymas. Žiūrèta 2021-09-07. 
- naujụjų amerikiečių ịtraukimas ị sprendimų priemimą ir igyvendinimą;

- profesinio tobulejimo galimybių darbuotojams ir savanoriams sudarymas;

- paslaugų, atitinkančiu konkrečios bibliotekos konkrečios bendruomenès poreikius, kūrimas;

- daugiakalbių išteklių kūrimas;

- ryšių tarp gyventojų ir naujųjų amerikiečiu skatinimas;

- tvarių paslaugų kūrimas ${ }^{57}$.

Kaip rodo naujausi tyrimai, naujieji šalių gyventojai viešosiomis bibliotekomis naudojasi šiais tikslais: 1) dalyvauja programose (kalbų mokymo); 2) naudojasi informacijos ištekliais ir kolekcijomis (skolinasi knygas); 3) naudojasi paslaugomis (pavyzdžiui, „Klausk bibliotekininko“)58. JAV naujieji gyventojai (imigrantai, pabègèliai ir perkeltieji asmenys) sudaro 13 proc. šalies populiacijos. Ši visuomenès dalis dažnai kreipiasi ị bibliotekas nemokamų ir patikimų paslaugų. Daugiau kaip 55 proc. naujųjų gyventojų kreipiasi i viešąsias bibliotekas bent kartą per savaitę, norèdami dalyvauti anglų kalbos pamokose, pilietiškumo ir pilietinio ugdymo programose ir gauti gyvybiškai svarbią galimybę bendrauti ${ }^{59}$. Imigrantų naudojimosi viešosiomis bibliotekomis padariniai - padidèjęs pasitikejjimas, išaugęs bendruomenès sąmoningumas, spartesnè kultūrinè ir politinè integracija, greičiau užmegzti ryšiai su žmonèmis (pavyzdžiui, draugyste்) ${ }^{60}$.

Lietuvos viešujų biblioteku veikla, prisidedant prie imigrantų integracijos procesų. 2020 metų statistikos duomenimis, Lietuvoje veike 1226 viešosios bibliotekos: 5 apskričių viešosios bibliotekos ir 60 savivaldybių viešųjų bibliotekų, turinčių 122 miesto, 1030 kaimo, 9 vaikų filialus ${ }^{61}$. Viešosios bibliotekos sudaro per 53 proc. visų šalies bibliotekų. Viešujų bibliotekų tinklas - tankiausias institucinis kultūros ịstaigų tinklas šalyje, pasiekiantis ir atokių vietovių gyventojus. 68 proc. Lietuvos gyventojų bibliotekų prieinamumą vertina kaip gerą ir labai gerą ${ }^{62}$. Migrantų situacija, bent kol kas, neturi Lietuvos bibliotekoms tokio tiesioginio ir aiškaus poveikio kaip COVID-19 pandemija. Tačiau prielaidos daugiakultūrei bibliotekai rastis jau buvo kuriamos pastarąji dešimtmetị. Bibliotekų veiklai teikiant paslaugas pabėgèliams 2018 m. gairèse rekomenduojama:

- remtis kitų Europos šalių bibliotekų, kuriose jau aptarnaujami pabėgèliai, pavyzdžiais;

- plètoti konsultavimo ir aptarnavimo paslaugas pabėgèliams, padèti jiems suprasti, kaip veikia socialinès tarybos;

- padèti pabègèliams ugdyti reikiamus kalbos igūdžius;

- ypač skirti dèmesị pabėgèlių vaikams, padèti išsigydyti psichologines persikèlimo traumas;

- skleisti vietos bendruomenèms informaciją apie pabėgèlių gyvenimo realijas, jų kultūrą ir priežastis, dèl kurių jie tapo pabègèliais;

- atverti bibliotekas kaip dialogo erdves ir siekti bendruomenès sutelktumo ${ }^{63}$.

Apibendrinant viešosios bibliotekos misiją ir pasaulio viešųjų bibliotekų patirtị kuriant ir teikiant paslaugas imigrantams ir siekiant ją pritaikyti Lietuvos viešosioms bibliotekoms dviejų krizių kontekste, formuluotinos šios įžvalgos:

ALA (American Library Association): Releases Recommendations for Improved Public Library Services to New Americans. Prieiga per internetą: https://www.ala.org/news/press-releases/2019/07/ala-releases-recommendations-improved-public-library-services-new-americans. Žiūrèta 2021-08-23.

58 Žr. Grossman, S.; Agosto, D. E.; Winston, M.; Epstein, R.; Nancy E.; Cannuscio, C. C.; Martinez-Donate, A.; Klassen, A. C. How Public Libraries Help Immigrants Adjust to Life in a New Country: A Review of the Literature. Health Promotion Practice, First Published March 31, 2021. Doi: https://doi.org/10.1177/15248399211001064

59 Žr. New Americans Library Project: An Initiative the American Library Association: About. Prieiga per internetą: https://newamericans.ala.org/about/. Žiūrèta 2021-09-24.

60 Žr. Grossman, S.; Agosto, D. E.; Winston, M.; Epstein, R.; Nancy E.; Cannuscio, C. C.; Martinez-Donate, A.; Klassen, A. C. How Public Libraries Help Immigrants Adjust to Life in a New Country: A Review of the Literature.

${ }_{61}$ Bendroji 2020 metu bibliotekų ataskaita. Biblioteku statistiniai duomenys. Prieiga per internetą: https://www.lnb.lt/informacijos-mokslu-specialistams/lietuvos-biblioteku-statistika/biblioteku-statistiniai-duomenys. Žiūrèta 2021-05-09.

62 Naujausias tyrimas rodo - viešosios bibliotekos gerina lankytoju gyvenimo kokybę. LNB.lt. 2020.01.30. Prieiga per internetą: https://www.lnb.lt/naujienos/5059-naujausias-tyrimas-rodo-viesosios-bibliotekos-gerina-lankytoju-gyvenimo-kokybe. Žiūrèta 2021-05-05.

63 Žr. Daugiakultūrio dialogo biblioteka: darbo su migrantais gairès. 
- viešųjų bibliotekų kuriamas bendruomeniškumas ir sąmoningumas daro įtaką visuomenei; bibliotekų veiklos kryptys turètų būti orientuotos ị stabilumo sociume kūrimą, susipriešinimo mažinimą, konstruktyvų dialogą;

- būtina numatyti planus darbuotojų kompetencijoms ugdyti ar pasitelkti reikalingas kompetencijas turinčius darbuotojus ar savanorius - pavyzdžiui, lietuvių ir anglų kalbų mokytojus, vertëjus;

- prioritetinè kryptis - dèmesys ankstyvajam migrantų vaikų ugdymui, pagalba jiems mokytis;

- būtina suteikti nemokamą interneto prieigą.

\section{Lietuvos viešųjų bibliotekų pastangos užtikrinti žmogaus teises: empirinis tyrimas}

\subsection{Tyrimo tikslas, metodai, tyrimo dalyviai ir klausimai}

IFLA 2019-2020 m. kartu su suinteresuotomis šalimis vykdè tyrimus, padedančius atskleisti bibliotekų indèli i žmogaus teisių igyvendinimą. Sekdama jų pavyzdžiu Lietuvos bibliotekininkų draugija (LBD) $2021 \mathrm{~m}$. inicijavo tyrimą „Lietuvos viešosios bibliotekos - žmogaus teisių igyvendinimui“. Siekta nustatyti, kaip Lietuvos viešosios bibliotekos padeda igyvendinti žmogaus teises, bibliotekų pasiekimus šioje srityje ir galimybes bibliotekoms siekti didesnių šios srities tikslų. Tyrimo klausimyną sudarè, gautus rezultatus apibendrino ir LBD tarybai pateikè šio straipsnio autoré.

Tyrimas atliktas anketinès apklausos metodu, nuoroda i klausimyną pateikta internetu. Sudarytą pusiau struktūruotą tyrimo klausimyną LBD taryba patvirtino $2021 \mathrm{~m}$. balandžio mènesị. Jị sudaro 14 klausimų, suskirstytų i 6 blokus:

I. Teisè gauti informaciją (6 klausimai)

II. Teisè ị švietimą ir mokymą(si) (3 klausimai)

III. Lygių teisių visiems visuomenès nariams sudarymas. Nediskriminavimas (1 klausimas)

IV. Teisė dalyvauti bendruomenès kultūriniame gyvenime (2 klausimai)

V. Teisè ị sveikatą (1 klausimas)

VI. Žmogaus teisių suvokimo didinimas (1 klausimas)

Pateiktame kiekvieno klausimo atsakymų variantų meniu tyrimo dalyviai galëjo žymėti visus jiems tinkamus atsakymų variantus; buvo sudarytos dvi papildomos galimybès: a) pasirinkti atsakymo variantą „kita“ ir b) pateikti savo pavyzdžių. Tyrimo dalyvių buvo paprašyta įvardyti tik reikšmingiausius, dideli poveikị turejusius veiklos užtikrinant žmogaus teises pavyzdžius.

Tyrimas atliktas $2021 \mathrm{~m}$. gegužès mènesį. Dalyvavo 105 viešosios bibliotekos ir jų filialai ( 8,6 proc. šalies viešujų bibliotekų). Gauti rezultatai apibendrinti tų pačių metų birželio mẻneși ir pateikiami apskaičiuojant gautų atsakymų procentinę išraišką nuo bendro tyrimo dalyvių skaičiaus. Atsakymai anoniminiai.

Tyrimo metu gauti duomenys šiame straipsnyje papildomi ir iliustruojami straipsnio autorès dar vieno, 2020 m. kovo 23-31 d. atlikto, empirinio tyrimo rezultatais (t. y. viešųjų bibliotekų gerosios praktikos pavyzdžiais, esant šalyje paskelbtam karantinui) ${ }^{64}$.

\subsection{Empirinio tyrimo rezultatai}

Biblioteka visiems. Lietuvos viešosios bibliotekos teikia paslaugas visiems besikreipiantiems žmonèms ir lankytojams. İ šalies viešųjų bibliotekų akiratị patenka ir asmenys, dèl įvairių priežasčiu negalintys savarankiškai naudotis bibliotekų paslaugomis ir patiriantys fizinę, socialinę, informacinę ir technologinę atskirtị (negalią turintys žmonės - 92,4 proc.; besigydantys ligoninėse ir gyvenantys slaugos namuose asmenys - 31,4 proc.; laisvès suvaržymų turintys asmenys - 14,3 proc.). Pastaruoju metu visuomenèje pastebimai dideja poreikis pritaikyti informacijos ir bibliotekų paslaugas skaitymo sutrikimų ir sunku-

Apie šį tyrimą plačiau žr. Januševičienè, R. Lietuvos viešosios bibliotekos pirmosiomis karantino savaitėmis, p. 13-15. 
mų (autizmo spektro sutrikimai, disleksija) turintiems žmonėms. Lietuvos viešosiose bibliotekose nuo 2020 m. taikomi infrastruktūriniai sprendimai, ugdomos darbuotojų kompetencijos, kuriamos naujos paslaugos autizmo spektro ir kitų komunikacijos, kalbos, elgesio sutrikimų turintiems žmonèms ${ }^{65}$.

Patikimumas ir socialine atsakomybè. Per karantiną užsidarius beveik visoms ịstaigoms, itin išryškejo dalies visuomenès technologinė atskirtis. Namuose neturintys kompiuterio senjorai patyrè dvigubą atskirtị - dèl ịprasto pasaulio užsidarymo per karantiną ir dèl negalëjimo naudotis virtualiomis paslaugomis. Lietuvos viešosios bibliotekos ne tik itin operatyviai ir lanksčiai prisitaike dirbti naujomis sąlygomis, bet ir mokè gyvenimo naujoje realybeje igūdžių savo vartotojus. Bibliotekos skelbė (interneto svetainèse, telefonu, informaciniais plakatais bibliotekų pastatų languose ir kt.) oficialių šaltinių (Sveikatos apsaugos ministerijos, savivaldybių) pateikiamą aktualią informaciją, teikè kitą informaciją pagal vartotojų užklausas ir poreikius.

Viešosios bibliotekos yra patikimos institucijos, saugančios vartotojų, autorių, leidejjų, kitų suinteresuotų grupių ir darbuotojų asmens duomenis. 2018 m. Lietuvos Respublikos kultūros ministro ịsakymu buvo patvirtintos Asmens duomenų tvarkymo bibliotekoje pavyzdinès taisyklès ${ }^{66}$. Lietuvos Respublikos Vyriausybei $2021 \mathrm{~m}$. rugpjūčio mèn. paskelbus apie planuojamas nuo rugsẻjo 13 d. ịvesti naujas pandemijos valdymo priemones (didelè svarba ir reikšmè teikiama galimybių pasui), kilo dalies visuomenès nepasitenkinimas. Socialiai jautrioms visuomenès grupėms, ypač naujosiomis technologijomis nesinaudojantiems senjorams, iškilo (kyla) nepatogumų, norint ịsigyti ši dokumentą. Pagalbą šiai visuomenès kategorijai operatyviai - jau rugpjūčio pradžioje - pasiūlè ir viešosios bibliotekos: jose vartotojai gali elektronine ar spausdintine forma nemokamai įsigyti galimybių pasą ${ }^{67}$.

Viešosios bibliotekos kūrè naujų formų renginius, plačiau naudojo socialinių tinklų teikiamas galimybes, ịvairiais būdais (biblioterapijos užsièmimai, virtualūs skaitytojų klubai, kūrybinis rašymas) padèjo vartotojams kovoti su dèl pandemijos patiriamu nerimu ir nežinia. Iki karantino literatūrą kūrè, tinklaraščiuose rašè daugiau kaip 230 tūkst. vyresnių nei 15 metų Lietuvos gyventojų. 2020 m., palyginti su 2017 m. duomenimis, tinklaraščių buvo rašoma 3 proc. daugiau, grožinès ir negrožinès literatūros kuriama 2 proc. ${ }^{68}$ daugiau. Viešųjų bibliotekų kūrybinio rašymo dirbtuvėse dalyvavę vartotojai, gyvenantys tiek Lietuvos teritorijoje, tiek užsienyje, pripažino, kad šis užsièmimas padejo jiems išlieti susikaupusi nerimą, pasijusti bibliotekos bendruomenès dalimi.

Karantinas aiškiai atskleide knygų ir skaitymo poreikị. Net griežčiausių ribojimų sąlygomis Lietuvos viešosios bibliotekos rado būdų pagelbèti skaitytojams. Pavyzdžiui, Vilniaus miesto savivaldybès centrinejje bibliotekoje knygos buvo skaitomos telefonu ${ }^{69}$. Verta atskirai paminèti savanorius knygnešius - tai skatinanti visuomenès socialinę atsakomybę veikla.

Laisve gauti informaciją. Ji Lietuvos viešosiose bibliotekose labiausiai suvokiama kaip nemokamos informacijos prieigos sudarymas (94,3 proc.), nemokamas skaitmeninių irankių ir priemonių suteikimas (69,5 proc.), elektroninių išteklių kaupimas ir sklaida. Pažymėtinas ir bibliotekų darbuotojų indèlis kuriant ịvairų turinị vartotojams, teikiant nuotolines paslaugas, informuojant ir konsultuojant vartotojus, mokant juos kompiuterinio raštingumo. Tyrimų duomenys rodo, kad skaitmeninių igūdžių labiausiai sto-

Lietuvos viešosios bibliotekos nuo šiol pritaikytos autizmo spektro sutrikimų turintiems lankytojams. Lietuvos Respublikos kultūros ministerija, 2020.11.18. Prieiga per internetą: https://rkm.lrv.lt/lt/naujienos/lietuvos-viesosios-bibliotekos-nuo-siol-pritaikytos-turintiems-autizmo-spektro-sutrikimu-lankytojams. Žiūrèta 2021-05-05.

66 Dèl asmens duomenu tvarkymo bibliotekoje pavyzdiniu taisykliu patvirtinimo / Patvirtinta LR kultūros ministro $2018 \mathrm{~m}$. gruodžio $4 \mathrm{~d}$. ịsakymu Nr. IV-937. Prieiga per internetą: https://e-seimas.lrs.lt/portal/legalAct/lt/TAD/7d8c6d01f80511e895b0d54d3db20123?positionInSearchResults=49\&searchModelUUID=a4880fda-18bf-4c22-911b-3ed901532a73. Žiūreta 2021-08-17.

67 Bibliotekos padès išsiimti Galimybiu pasą. Atspindžiai, 2021.08.09. Prieiga per internetą: https://www.atspindziai.lt/bibliotekos-pades-issiimti-galimybiu-pasa. Žiūrèta 2021-08-30.

68 Plačiau žr. Kūrybinio-terapinio rašymo dirbtuvès grižta ị Jonavą. Jonavos rajono savivaldybés viešoji biblioteka, 2020.11.03. Prieiga per internetą: https://jonbiblioteka.lt/kurybinio-terapinio-rasymo-dirbtuves-jonavoje-grizta-. Žiūrèta 2021-05-06.

69 Nauja nuotolinè paslauga senjorams: knygų skaitymas telefonu. Vilniaus miesto savivaldybès centriné biblioteka, 2020.04.14. Prieiga per internetą: https://www.vcb.lt/nauja-nuotoline-paslauga-senjorams-knygu-skaitymas-telefonu/. Žiūrèta 2021-05-06. 
koja kaimiškųjų rajonų gyventojai, ypač senjorai. Gerinti situaciją Lietuvos viešosios bibliotekos siekia kartu su iniciatyva „Prisijungusi Lietuva: efektyvi, saugi ir atsakinga Lietuvos skaitmeninè bendruomené. Šiuo projektu siekiama padèti gyventojams efektyviai, saugiai, atsakingai naudotis internetu ir skaitmeninemis technologijomis. Gyventojų skaitmeniniam raštingumui gerinti pasitelkiama bibliotekos viešosios interneto prieigos taškų infrastruktūra ir žmogiškieji ištekliai (ị iniciatyvą įsitrauke 1200 bibliotekininkų). Kai kurios bibliotekos per pastaruosius dvejus metus moke kompiuterinio raštingumo daugiau kaip 1000 gyventojų $u^{70}$. Igijusiems pradiniu igūdžių vartotojams bibliotekos kuria mokomuosius filmukus: kaip užsisakyti knygas naudojantis bibliotekos elektroninių katalogu; kaip naudotis elektroninemis paslaugomis.

Kokybiška informacija iš patikimu šaltinių. Patikimais šaltiniais bendruomenei informuoti, bendruomeniškumui, socialinei ir kultūrinei įtraukčiai didinti bibliotekos įvardija oficialios informacijos šaltinius, valstybės institucijų tinklalapiuose skelbiamą informaciją, bibliotekos prenumeruojamas duomenų bazes, viešosios informacijos rengèjų teikiamas žinias. Lietuvos viešosios bibliotekos taip pat pačios kuria, skaitmenina, teikia viešajai prieigai kraštotyrinę informaciją.

Per pandemiją itin išaugo (socialiniuose tinklalapiuose ypač padaugejjus melagingų žinių) informacijos turinio ir patikimumo svarba. Lietuvos viešosios bibliotekos prisidèjo prie visuomenés medijų ir informacinio raštingumo didinimo:

- renginiais, akcijomis, mokymais (95 proc.);

- pagalba atliekant paiešką internete (94,3 proc.);

- pagalba atpažizstant netikras naujienas (per 57 proc.);

- paskaitomis, diskusijomis apie kibernetinị saugumą (53,3 proc.).

Šios veiklos orientuojamos ị šiuo atžvilgiu labiausiai pažeidžiamas grupes - vaikus ir senjorus. Organizuojamos Saugesnio interneto savaitės, mokymai vyksta žaidimo forma, rodomi filmukai apie asmens duomenų apsaugą, internete pasitaikančius pavojus.

Teise i švietima. Lietuvos viešosios bibliotekos prisideda prie neformaliojo (76 proc.) ir formaliojo (38 proc.) švietimo. Jau $2015 \mathrm{~m}$. duomenimis, ugdymo veikloje dalyvavo itin daug Lietuvos bibliotekų lankytojų - 75 proc. (ES vidurkis - 25 proc.). Lietuvos viešosiose bibliotekose vykdomos neformaliojo švietimo veiklos: mokymai gyventojams (78 proc.), edukacijos ( 80 proc.), būreliai, klubai (43,8 proc.). Bibliotekos bendradarbiauja su švietimo institucijomis, pedagogais, mokyklų bibliotekininkais, senjorų organizacijomis, rengia užsienio kalbų mokymus (igyvendinant suaugusiųjų neformaliojo švietimo programas), stovyklas vaikams. Tarp neformaliojo švietimo veiklų rengiamos ir paskaitos žmogaus teisių temomis. Gyventojai taip pat mokomi verslumo, fotografijos, robotikos, dailès ir kitų sričių igūdžių.

Prisidèdamos prie formaliojo švietimo, bibliotekos nuolat bendradarbiauja su švietimo institucijomis (49,5 proc.). Tai vyksta iggyvendinant projektus (39 proc.) ar epizodiškai (47 proc.). Itin išryškejo bibliotekų vaidmuo užtikrinant teisę ị mokymąsi karantino laikotarpiu. Šalies mokykloms 2020 m. perejjus prie nuotolinio mokymo, Lietuvos Respublikos kultūros ministerija ir Nacionaliné biblioteka reagavo i Švietimo, mokslo ir sporto ministerijos kreipimąsi aprūpinti kompiuteriais mokinius ir mokytojus, siekiant užtikrinti galimybes mokyti(-s) nuotoliniu būdu. Per 3000 viešųų bibliotekų tinklui skirtų stacionariųjų kompiuterių, kuriuos Nacionalinè biblioteka buvo įsigijusi pagal ES programą, pagal paslaugos sutartị buvo laikinai perduoti savivaldybėms ${ }^{71}$. Šis bibliotekų veiksmas yra reikšmingas ir prasmingas siekiant užtikrinti vaikų, augančių socialiai jautrioje aplinkoje, mažas pajamas gaunančiose šeimose, teisę mokytis, nes tai yra reali pagalba užtikrinant šią teisę.

Itraukties didinimas. Lietuvos viešosios bibliotekos kuria ir teikia paslaugas šioms dèl įvairių priežasčių atskirtị patiriančioms gyventojų grupėms:

Prisijungusi Lietuva: efektyvi, saugi ir atsakinga Lietuvos skaitmenine bendruomené. Prieiga per internetą: https://www.prisijungusi. 1t/apie-projekta. Žiūrèta 2021-05-05.

${ }^{71}$ Bibliotekos teikia pagalbą mokykloms: laikinai skolina naujus kompiuterius. $t v 3 . l t, 2020.04 .09$. Prieiga per internetą: https://www.tv3. lt/naujiena/lietuva/bibliotekos-teikia-pagalba-mokykloms-laikinai-skolina-naujus-kompiuterius-n1038332. Žiūrèta 2021-05-11. 
- senjorams (95 proc.);

- negalią turintiems asmenims (76,2 proc.);

- bedarbiams, darbo netekusiems asmenims (72,4 proc.);

- mažas pajamas gaunančioms šeimoms (65,7 proc.);

- tautinių mažumų atstovams (26,7 proc.);

- turintiems laisvès apribojimų asmenims (19 proc.);

- nedirbančiam ir nesimokančiam jaunimui (2,3 proc.).

Tyrimo metu pateikti viešųjų bibliotekų paslaugų pavyzdžiai:

- specialiųjų formatų leidiniai (25,7 proc.);

- erdvių pritaikymas, sensorinès erdvès (59 proc.);

- i̇rangos pritaikymas, daugiausia regos negalią turintiems žmonèms (40 proc.).

Atliekant tyrimą taip pat minèta knygnešystė (kai kuriose bibliotekose bendradarbiaujama su socialiniu taksi), pagalba imigrantų šeimų vaikams ir imigrantų šeimų konsultavimas (kaip naudotis valstybès e. sistemomis), gido kurtiesiems kūrimas, bendradarbiavimas su ịkalinimo ịstaigomis, dienos užimtumo centrais. Tačiau kai kurių bibliotekų patalpos tik iš dalies pritaikytos ar išvis nepritaikytos žmonėms, turintiems negalią; neteikiamos specialios paslaugos (negalią turintys ar senyvo amžiaus gyventojai gali naudotis tik tomis pačiomis paslaugomis kaip visi bibliotekos vartotojai).

Itrauktis ị kultürini gyvenimą. Bibliotekos savo kaupiamais informacijos ištekliais (66,7 proc.), renginiais ir programomis (87,6 proc.), vykdomomis kraštotyros veiklomis ( 80 proc.), kurdamos skaitmenini turinį, užtikrindamos jo prieigą (47,6 proc.), kurdamos skaitmeninius archyvus ir jų prieigą (38 proc.) sudaro skaitytojams galimybę pažinti šalies ir pasaulio kultūros paveldą. Tarp bibliotekų kuriamų skaitmeninių produktų pavyzdžių paminètina mobilioji programèlè „Literatūrinis Alytus“, virtualus žaidimas „Pažink Kauno rajoną“, virtualus žemèlapis „Molètų rajono literatūriniai tiltai“, interneto svetainès („Vilnijos vartai“, „Raseinistika“ ir kt.).

31,4 proc. bibliotekų prisideda prie tautinių mažumų atstovų teisès dalyvauti kultūriniame gyvenime užtikrinimo. Ne visų bibliotekų veikloje teikta dėmesio tautinėms mažumoms skirtoms paslaugoms kurti - tai gali būti ir dèl demografinès aptarnaujamos bendruomenès sudèties („mūsų mieste beveik nèra tautinių mažumų atstovų"). Valstybės pasienio teritorijose veikiančios bibliotekos kaupia literatūrą lenkų, rusų kalbomis, bendrauja su lankytojais latvių kalba. Pažymètina, kad per viešąsias bibliotekas labiau vyksta natūralūs tautinių mažumų integracijos procesai („rajone gyvena gausi romų bendruomenè. Jos atstovai dažnai bibliotekoje naudojasi interneto prieiga"). Šiems integracijos procesams pagreitinti bibliotekose ir organizuojami proginiai renginiai tautinių mažumų kultūrai reikšmingiems įvykiams paminèti. Kai kurios bibliotekos - pavyzdžiui, Vilniaus miesto centrinè biblioteka - jau turi ilgametį darbo su tautinių mažumų atstovais įdirbị organizuojant dienos stovyklas, užimtumo programas tautinių mažumų vaikams. Kita vertus, aktyvūs imigrantai ar laikinai Lietuvoje apsistoję kitų tautų atstovai patys mielai suranda veiklų viešosiose bibliotekose ir per jas skleidžia savo šalies kalbą ir kultūrą („,mūsų bibliotekoje prancūzų kalbos moko savanoris iš Belgijos").

Teise i sveikata. 79 proc. viešujų bibliotekų aktyviai prisideda prie teisès ị sveikatą užtikrinimo. Jos kaupia, teikia ir populiarina informaciją sveikatos, sveikatinimo, ligų prevencijos temomis (74,3 proc.), propaguoja sveiką gyvenseną (53,3 proc.), skatina ir organizuoja sveikos gyvensenos, kūno kultūros užsièmimus (39 proc.), kuria, teikia, populiarina paslaugas visuomenės psichikos sveikatai gerinti (38 proc.). Bibliotekos pateikia gerosios patirties pavyzdžių: bendradarbiavimas su Nacionaliniu visuomenès sveikatos centru, susitikimai su gydytojais, dietologais, vaistingųjų augalų specialistais; transliacijų apie sveiką mitybą ir sveiką gyvenseną kūrimas; mokymai naudotis valstybine sistema esveikata.lt; èjimo su šiaurietiškomis lazdomis populiarinimas; mankštu gyventojams organizavimas kartu su sveikatos apsaugos srities specialistais; seminarai streso valdymo temomis.

Žmogaus teisių suvokimo didinimas visuomenèje. Siekdamos, kad visuomenė turètų daugiau žmogaus teisių srities žinių, bibliotekos: 
- renka, kaupia, skelbia informaciją šiomis temomis (54,3 proc.);

- rengia susitikimus, paskaitas (36,2 proc.);

- rengia ịvairų turinị, didinantị visuomenès žinias apie žmogaus teises (33,3 proc.);

- rengia diskusijas (20 proc.).

Bibliotekose minima Europos diena, rengiami susitikimai su politikais, filosofais, vyksta pretendentų i valdžios institucijas debatai.

\section{Išvados ir rekomendacijos}

Pandemijos ir migracijos krizès neišvengiamai sukelia žmogaus teisių ir laisvių dilemas: siekiant išsaugoti gyvybes, įvedami judèjimo laisvès ir kiti ribojimai (sumažinantys galimybes gauti paslaugas, taip pat ir sveikatos apsaugos sistemos); viena vertus, gausiai atvykusiems migrantams dèl ribotų išteklių ir neefektyvios imigrantų politikos neužtikrinamos žmogaus teisès, kita vertus, dèl jų buvimo šalyje kyla gyventojų nepasitenkinimas ir konfliktai. Ankstesnè imigracijos politika neduoda pageidaujamų integracijos rezultatų tiek nūdienos Vakarų pasaulyje, tiek Lietuvoje. Naujų krizių sąlygomis būtina globaliai persvarstyti žmogaus teisių modelį, ịvertinant Europos šalių galimybes ir pajègumus priimti migrantus ir juos integruoti.

Pasaulio ir Lietuvos viešujų bibliotekų patirtys pandemijos ir migracijos krizių laikotarpiu rodo, kad viešosios bibliotekos yra socialiai atsakingos, lanksčios, santykinai greitai ir efektyviai reaguojančios ị pokyčius ir atliepiančios bendruomenių poreikius institucijos. Kaip arčiausiai bendruomenių esančios kultūros ịstaigos, Lietuvos viešosios bibliotekos iki šiol daug prisidejjo prie žmogaus teisių užtikrinimo ir gali būti ypač naudingos visuomenei konsoliduoti tiek artimiausioje, tiek tolimoje perspektyvoje: siekdamos didesnio visuomenès informuotumo, skleisdamos patikimą informaciją iš patikimų šaltinių, kviesdamos i konstruktyvią diskusiją, skatindamos išgryninti vertybes, pagarbą ir dialogą.

Prisidedant prie nūdienos krizių sukeltų problemų (užtikrinant žmogaus teisių iggyvendinimą) sprendimų šalyje, viešosioms bibliotekoms rekomenduojama: 1) ypač skirti dèmesį medijų ir informacinio raštingumo veikloms ir programoms; 2) sparčiau gerinti fizinę ir informacinę viešujų bibliotekų infrastruktūrą, skirtą negalią turintiems žmonèms; 3) remiantis pasaulio viešųjų bibliotekų patirtimi, plèsti (tiek ị gylị, tiek ị plotị) viešųjų bibliotekų dalyvavimą migrantų socialinès integracijos programose; 4) rengti bendruomenès ir potencialių vartotojų poreikių tyrimus.

\section{Literatūra ir šaltiniai}

ALA (American Library Association): COVID-19 Recovery: Making Connections during Crisis and Plothing the Path to Reopening. Prieiga per internetą: https://www.ala.org/tools/covid-19-recovery. Žiūrèta 2021-08-23.

ALA (American Library Association): Releases Recommendations for Improved Public Library Services to New Americans. Prieiga per internetą: https://www.ala.org/news/press-releases/2019/07/ala-releases-recommendations-improved-public-library-services-new-americans. Žiürèta 2021-08-23.

Alytaus Jurgio Kunčino viešosios bibliotekos lankytoju nuomonès tyrimas apie mokslines paslaugas karantino metu / Parengè Indrè Lukoševičienè. Prieiga per internetą: http://www.alytus.mvb.lt/images/pdf/apklausos/ 2020nuotolines_paslaugos.pdf. Žiūrèta 2021-09-07.

Bibliotekos padès išsiimti Galimybių pasą. Atspindžiai, 2021.08.09. Prieiga per internetą: https://www.atspindziai. lt/bibliotekos-pades-issiimti-galimybiu-pasa. Žiūrèta 2021-08-30.

Bibliotekos teikia pagalbą mokykloms: laikinai skolina naujus kompiuterius. tv3.lt, 2020.04.09. Prieiga per internetą: https://www.tv3.lt/naujiena/lietuva/bibliotekos-teikia-pagalba-mokykloms-laikinai-skolina-naujus-kompiuterius-n1038332. Žiūrèta 2021-05-11.

Biblioteku pletros strategines kryptys 2016-2022 metams / Patvirtinta Lietuvos Respublikos kultūros ministro $2016 \mathrm{~m}$. balandžio 29 d. įsakymu Nr. IV-344. Prieiga per internetą: https://lrkm.lrv.lt/uploads/lrkm/documents/files/Biblioteku\%20pletros\%20kryptys.pdf. Žiūrèta 2021-08-27.

Bendroji 2020 metų bibliotekų ataskaita. Biblioteku statistiniai duomenys. Prieiga per internetą: https://www. lnb.lt/informacijos-mokslu-specialistams/lietuvos-biblioteku-statistika/biblioteku-statistiniai-duomenys. Žiūrèta 2021-05-09. 
Bortkevičiūtè, Rasa; Kalkytė, Patricija; Kuokštis, Vytautas; Nakrošis, Vitalis; Patkauskaitė-Tiuchtienė, Inga; Vilpišauskas, Ramūnas. Nuo greitu pergaliu prie skaudžiu pralaimẹjimų: Lietuvos viešosios politikos atsakas $i$ COVID-19 pandemiją ir šios krizés valdymas 2020 m. Vilnius: Vilniaus universiteto leidykla, 2021.

Bružaitè, Toma. Migracija yra neišvengiama:pokalbis su dr. Egle Verseckaite-Grzeskowiak. Bernardinai.lt, 2021.07.26. Prieiga per internetą: https://www.bernardinai.lt/migracija-yra-neisvengiama-pokalbis-su-dr-egle-verseckaite-grzeskowiak/. Žiūrèta 2021-09-10.

Choquet, Sabine. Models of Integration in Europe. European Issue, No. 449, 30th October 2017, p. 1-8. Prieiga per internetą: https://www.robert-schuman.eu/en/european-issues/0449-models-of-integration-in-europe. Žiūrèta 2021-08-27.

COVID-19 and the Global Library Field: Statement by the IFLA President and Secretary General, 23 March 2020. Prieiga per internetą: https://www.ifla.org/covid-19-and-libraries. Žiūrèta 2021-08-23.

COVID-19 and Human Rights: We are all in this together. United Nations, April 2020. Prieiga per internetą per internetą: https://www.un.org/victimsofterrorism/sites/www.un.org.victimsofterrorism/files/un_-_human_rights_and_covid_april_2020.pdf. Žiūrèta 2021-09-15.

Daugiakultūrio dialogo biblioteka: darbo su migrantais gairès / sudarytojos E. Dikavičienè, B. Dženkaitienė, D. Ivanovienè, E. Puskunigytė, A. Vaškevičienė, R. Zenevskienè. Vilnius: Lietuvos nacionalinė Martyno Mažvydo biblioteka, 2018. Prieiga per internetą: http://eia.libis.lt/show.php?item=daugiakulturinio_dia. Žiūrèta 2021-09-30.

Dèl asmens duomenu tvarkymo bibliotekoje pavyzdiniu taisykliu patvirtinimo / Patvirtinta LR kultūros ministro 2018 m. gruodžio 4 d. įsakymu Nr. IV-937. Prieiga per internetą: https://e-seimas.lrs.lt/portal/legalAct/ lt/TAD/7d8c6d01f80511e895b0d54d3db20123?positionInSearchResults=49\&searchModelUUID=a4880fda-18bf-4c22-911b-3ed901532a73. Žiūrèta 2021-08-17.

EBLIDA\&COVID-19: A European Library Agenda for the Post-Covid 19 Age Work in Progress. Prieiga per internetą: http://www.eblida.org/publications/eblida-and-covid-19.html. Žiūrèta 2021-08-27.

Frèjutė-Rakauskienė, Monika. Reali ar sukurta?: „pabėgèlių krizės“ vaizdavimas Lietuvos spaudos diskurse 20152017 metais. Informacijos mokslai, 2020, t. 88, p. 29-45. DOI: https://doi.org/10.15388/Im.2020.88.30

Genys, Dainius; Imbrasaitè, Jūratè. Pilietinès saviraiškos ir valstybinio paternalizmo konfigūracijos COVID-19 pandemijos laikotarpiu. Darbai ir dienos, 2021, t. 75, p. 113-126. DOI: https://doi.org/10.7220/2335-8769.75.7

Glosienè, Audronė; Petuchovaitè, Ramunė; Racevičiūtè, Rasa. Viešoji biblioteka: tradicija ir modernumas. Vilnius: Žara, 1998.

Glosienè, Audronè. Kūrybiškumas ir socialinis kapitalas žiniu visuomenëje: idëju žemèlapis. Vilniaus universiteto leidykla, 2010.

Grossman, Siuzane; Agosto, Denise E.; Winston, Marc; Epstein, Rabbi Nancy E.; Cannuscio, Carolyn C.; Martinez-Donate, Ana; Klassen, Ann C. How Public Libraries Help Immigrants Adjust to Life in a New Country: A Review of the Literature. Health Promotion Practice, First Published March 31, 2021. DOI: https://doi. org/10.1177/15248399211001064

IFLA/UNESCO Multicultural Library Manifesto: The Multicultural Library - A Gateway to a Cultural Diverse Society in Dialogue. International Federation of Library Associations and Institutions (IFLANET), 2006. Prieiga per internetą: http://archive.ifla.org/VII/s32/pub/MulticulturalLibraryManifesto.pdf. Žiūrèta 2021-08-27.

IFLA/UNESCO Public Library Manifesto 1994. Prieiga per internetą:https://www.ifla.org/node/91700. Žiūrèta 2021-09-22.

Ilkevičiūtè, Justina. Lietuvos ambasadorius ES: kaip pavyko sustabdyti Irako skrydžius ir kodèl Briuselis nefinansuoja sienos statybos. LRT.lt, 2021.08.23. Prieiga per internetą: https://www.lrt.lt/naujienos/pasaulyje/6/1472240/ lietuvos-ambasadorius-es-kaip-pavyko-sustabdyti-irako-skrydzius-ir-kodel-briuselis-nefinansuoja-sienos-statybos. Žiūrèta 2021-08-23.

Jačauskas, Ignas. Lietuvių kalbos pamokų rudenị sulauks per 160 migrantų vaikų, jų skaičius gali didėti. LRT.lt, 2021.08.29. Prieiga per internetą: https://www.lrt.lt/naujienos/lietuvoje/2/1479339/lietuviu-kalbos-pamoku-rudeni-sulauks-per-160-migrantu-vaiku-ju-skaicius-gali-dideti. Žiūrèta 2020-08-30. 
Januševičienė, Rasa. Lietuvos viešosios bibliotekos pirmosiomis karantino savaitemis. Tarp knygu, 2020, balandis, p. 13-15.

Jaruševičiūtė, Gailè. Navickienė: gavę prieglobsčio statusą, afganistaniečiai galès pasirinkti, ar likti Lietuvoje, ar ieškoti naujų galimybių. LRT.lt, 2021.08.26. Prieiga per internetą: https://www.lrt.lt/naujienos/lietuvoje/2/1476128/ navickiene-gave-prieglobscio-statusa-afganistanieciai-gales-pasirinkti-ar-likti-lietuvoje-ar-ieskoti-nauju-galimybiu. Žiūrèta 2021-09-10.

Juchnevič, Laura. Biblioteku vaidmenu kaita tinklaveikos visuomeneje: Lietuvos atvejis. Daktaro disertacija: socialiniai mokslai, komunikacija ir informacija (08 S). Vilnius: Vilniaus universitetas, 2016. Prieiga per internetą: http://www.kf.vu.lt/dokumentai/Mokslas/L._Juchnevic_disertacija_2015-12-14.pdf. Žiūrèta 2021-05-06.

Kultūros ministras S. Kairys: artējantis naujas kultūros sezonas taps laisvesnis ir intensyvesnis. Lietuvos Respublikos kultūros ministerija, 2021.08.17. Prieiga per internetą: lrkm.lrv.lt/lt/naujienos/kulturos-ministras-s-kairys-artejantis-naujas-kulturos-sezonas-taps-laisvesnis-ir-intensyvesnis. Žiūrèta 2021-08-23.

Kūrybinio-terapinio rašymo dirbtuvès grịžta ị Jonavą. Jonavos rajono savivaldybès viešoji biblioteka, 2020.11.03. Prieiga per internetą: https://jonbiblioteka.lt/kurybinio-terapinio-rasymo-dirbtuves-jonavoje-grizta-. Žiūrèta 2021-05-06.

Labanauskas, Liutauras. Rasistiniai išpuoliai, neapykantos nusikaltimai ir incidentai prieš imigrantus Lietuvoje. Filosofija. Sociologija, 2020, t. 31, Nr. 4, p. 283-290. DOI: https://doi.org/10.6001/fil-soc.v31i4.4344

Lahayne, Holger. Laisvė be epitetų: Friedrichas Hayekas ir kelias iš pandemijos vergovès. Naujasis Židinys-Aidai, 2021, Nr. 6, p. 13-18. Taip pat prieiga per internetą: https://nzidinys.lt/holger-lahayne-laisve-be-epitetu-friedrichas-hayekas-ir-kelias-is-pandemijos-vergoves-nz-a-nr-6/

Lahayne, Holger. Žmogaus teisių infliacija. Bernardinai.lt, 2020.09.28. Prieiga per internetą: https://www.bernardinai.lt/zmogaus-teisiu-infliacija/. Žiūrèta 2021-08-21.

Library Services for Immigrants: A Report of Current Practices. U.S. Citizenship and Immgration Services: Institute of Museum and Library Services. Prieiga per internetą: https://www.uscis.gov/sites/default/files/document/guides/G-1112.pdf. Žiūrèta 2021-08-23.

Lietuvos viešosios bibliotekos aktyviai prisideda igyvendinant Žmogaus teises: tyrimo ataskaita / Parengė Rasa Januševičienè. Lietuvos bibliotekininkų draugija, 2021 m. 5 p. [Rankraštis].

Lietuvos viešosios bibliotekos nuo šiol pritaikytos autizmo spektro sutrikimų turintiems lankytojams. Lietuvos Respublikos kultūros ministerija, 2020.11.18. Prieiga per internetą: https://lrkm.lrv.lt/lt/naujienos/ lietuvos-viesosios-bibliotekos-nuo-siol-pritaikytos-turintiems-autizmo-spektro-sutrikimu-lankytojams. Žiūrèta 2021-05-05.

Masevičienė, Alma. Daugiakultūrẻ kompetencija. In: Daugiakultūriškumas: inovatoriai ir ugdytojai bibliotekose: mokomasis paketas bibliotekoms / Erasmus+. Prieiga per internetą: https://ec.europa.eu/programmes/erasmus-plus/project-result-content/693ac91a-037e-4d0a-aa8a-4d5ac18b3abd/O3_Educational\%20materials_ LIT.pdf. Žiūrèta 2021-09-24.

Mažeikis, Gintautas. Beveidžiai pabėgèliai ir hibridinis karas. LRT.lt, 2021.07.08. Prieiga per internetą: https:// www.lrt.lt/naujienos/nuomones/3/1446484/gintautas-mazeikis-beveidziai-pabegeliai-ir-hibridinis-karas. Žiūrèta 2021-08-29.

Mažeikis, Gintautas. Iniršis ir beveidiškumas: migrantų krizè. LRT.lt, 2021.07.29. Prieiga per internetą: https:// www.lrt.lt/naujienos/nuomones/3/1458802/gintautas-mazeikis-inirsis-ir-beveidiskumas-migrantu-krize. Žiūrèta 2021-08-29.

Musnickas, Raigardas. „ES turi sukrusti ir suprasti“ - krizès akivaizdoje Linkevičius palaiko griežtesnę migracijos politika. LRT. lt, 2021.08.24. Prieiga per internetą: https://www.lrt.lt/naujienos/pasaulyje/6/1475213/es-turi-sukrusti-ir-suprasti-krizes-akivaizdoje-linkevicius-palaiko-grieztesne-migracijos-politika. Žiūrèta 2021-08-24.

Nauja nuotolinè paslauga senjorams: knygų skaitymas telefonu. Vilniaus miesto savivaldybès centrine biblioteka, 2020.04.14. Prieiga per internetą: https://www.vcb.lt/nauja-nuotoline-paslauga-senjorams-knygu-skaitymas-telefonu/. Žiūrèta 2021-05-06. 
Naujausias tyrimas rodo - viešosios bibliotekos gerina lankytoju gyvenimo kokybę. LNB.lt, 2020.01.30. Prieiga per internetą: https://www.lnb.lt/naujienos/5059-naujausias-tyrimas-rodo-viesosios-bibliotekos-gerina-lankytoju-gyvenimo-kokybe. Žiūrèta 2021-05-05.

Neteisètos migracijos stebėsena. Lietuvos statistikos departamentas. Prieiga per internetą: https://ls-osp-sdg.maps. arcgis.com/apps/dashboards/9b0a008b1fff41a88c5efcc61a876be2. Žiūrèta 2021-08-23.

Norkus, Zenonas. Ar galime gyventi geriau? Velfarizmas ir jo alternatyvos. Politologija, 2004, t. 4, Nr. 36, p. 3-39. Taip pat prieiga per internetą: https://www.fsf.vu.lt/users/zennor/pub/Velfarizmas_ir_jo_alternatyvos.pdf. Žiūrèta 2021-08-23.

Pabégèliu integracija Lietuvoje: dalyvavimas ir igalinimas: integracijos Lietuvoje suvokimas pagal amžiaus, lyties ir ¡̇vairovés aspektais grindžiama dalyvaujamaji metodą: $2013 \mathrm{~m}$. spalio-lapkričio mèn. Jungtinių Tautų vyriausiojo pabėgèlių reikalų komisaro biuras, 2014 m. rugsėjo mėn. Prieiga per internetą: https:/www.refworld.org/cgibin/texis/vtx/rwmain/opendocpdf.pdf?reldoc=y\&docid=58a486ef1. Žiūrèta 2021-09-30.

Pankūnas, Gytis. Vyriausybė nutarè: Lietuva priims ir apgyvendins iki 200 Afganistano piliečių. LRT.lt, 2021.08.25. Prieiga per internetą: Irt.lt/naujienos/lietuvoje/2/1475626/vyriausybe-nutare-lietuva-priims-ir-apgyvendins-iki200-afganistano-pilieciu. Žiūrèta 2021-08-25.

Patvirtintos naujos pandemijos valdymo priemonès. Korona stop, 2021.08.11. Prieiga per internetą: https://koronastop.lrv.lt/lt/naujienos/patvirtintos-naujos-pandemijos-valdymo-priemones. Žiūrèta 2021-08-23.

Pažintis su novatoriška Suomijos biblioteku patirtimi imigrantu ir pabègeliu srityse. Lietuvos nacionalinė Martyno Mažvydo biblioteka, 2018.04.09. Prieiga per internetą: lnb.lt/naujienos/3034-pazintis-su-novatoriska-suomijos-biblioteku-patirtimi-imigrantu-ir-pabegeliu-srityse. Žiūrèta 2021-08-21.

Petuchovaitè, Ramunè. Viešujų bibliotekų paslaugų bendruomenei plètra: sèkmingos praktikos Lietuvoje ir tarptautiniu veiksmu studija. Vilniaus universiteto leidykla, 2004.

Pilkūnè, Dalia. Dèl suintensyvejjusių nelegalios migracijos srautų paskelbta valstybès lygio ekstremali situacija. Delfi, BNS, 2021.07.02. Prieiga per internetą: https://www.delfi.lt/news/daily/lithuania/del-suintensyvejusiu-nelegalios-migracijos-srautu-paskelbta-valstybes-lygio-ekstremali-situacija.d?id=87621349. Žiūrèta 2021-09-10.

Prisijungusi Lietuva: efektyvi, saugi ir atsakinga Lietuvos skaitmenine bendruomene. Prieiga per internetą: https://www.prisijungusi.lt/apie-projekta. Žiūrèta 2021-05-05.

Sultanova, Leila; Milto, Liudmila; Zheludenko, Maryna. The Impact of the COVID-19 Pandemic on the Development of Higher Education. Acta Paedagogica Vilnensia, 2021, t. 46, p. 132-147. DOI: https://doi.org/10.15388/ActPaed.46.2021.9

Šakalienè, Dovilè. Kas valdo Europą: žmonių kontrabandininkai ar ịstatymai? LRT.lt, 2021.09.20. Prieiga per internetą: https://www.lrt.lt/naujienos/pozicija/679/1499817/dovile-sakaliene-kas-valdo-europa-zmoniu-kontrabandininkai-ar-istatymai. Žiūrèta 2021-09-21.

Telešienè, Audronė; Balžeikienè, Aistė; Budžytė, Agnė; Zolubienė, Eimantè. COVID-19 rizikos suvokimas ir socialiniai daugikliai Lietuvoje. Filosofija. Sociologija, 2021, t. 32, Nr. 2, p. 95-104. DOI: https://doi.org/10.6001/ fil-soc.v32i2.4409

Tarpkultūrinis ir informacinis migrantų švietimas - personalo kompetenciju ugdymas. Lietuvos nacionalinė Martyno Mažvydo biblioteka. Prieiga per internetą: lnb.lt/apie-biblioteka/veiklos-sritys/programos-ir-projektai/kvalifikacijos-kelimas-mokymai/tarpkulturinis-ir-informacinis-migrantu-svietimas-personalo-kompetenciju-ugdymas. Žiūrèta 2021-09-07.

Visuotiné Žmogaus teisių deklaracija. Prieiga per internetą: urm.lt/uploads/default/documents/uzienio_politika/ zmogaus_teises/Visuotine_zmogaus_teisiu_deklaracija.pdf. Žiūrèta 2021-08-26.

Žibas, Karolis, Platačiūtè, Vita. Migrantų integracija ir migracijos tinklai Lietuvoje: nuo teorinių veiksnių iki empirinių duomenų. Oikos: lietuvių migracijos ir diasporos studijos, 2014, Nr. 2 (18), p. 7-22. DOI: https://hdl.handle. net/20.500.12259/32487

Žiliukaitè, Rūta; Poviliūnas, Arūnas; Savicka, Aida. Lietuvos visuomenès vertybių kaita per dvidešimt nepriklausomybes metu. Vilniaus universitetas, 2016.

Žmogaus teisès Lietuvoje 2018-2019: apžvalga / redakcinè grupė: G. Jurevičiūtè, M. Adutavičiūtė, U. Grigaitė, E. Leonaitè, D. Pūras. Vilnius: Žmogaus teisių stebėjimo institutas, 2020. 